NBER WORKING PAPER SERIES

\title{
HOW UNIVERSITY ENDOWMENTS RESPOND TO FINANCIAL MARKET SHOCKS: EVIDENCE AND IMPLICATIONS
}

\author{
Jeffrey Brown \\ Stephen G. Dimmock \\ Jun-Koo Kang \\ Scott Weisbenner \\ Working Paper 15861 \\ http://www.nber.org/papers/w15861 \\ NATIONAL BUREAU OF ECONOMIC RESEARCH \\ 1050 Massachusetts Avenue \\ Cambridge, MA 02138 \\ April 2010
}

This paper previously circulated under the title "Why I Lost My Secretary: The Effect of Endowment Shocks on University Operations." We are grateful to seminar participants at Aalto University, Chinese University of Hong Kong, City University of Hong Kong, DePaul University, Hebrew University, ISCTE Business School Conference, Korea University, Maastricht University, Miami University, MSU Federal Credit Union Conference on Financial Institutions and Investments, NBER Summer Institute, Stockholm School of Economics, Tel Aviv University, University of Hong Kong, University of Illinois, University of Iowa, the Vienna Endowment Workshop, and West Virginia University and Warren Bailey, Bo Becker, Dan Bergstresser, Lauren Cohen, Elroy Dimson, Ron Ehrenberg, Vidhan Goyal, Harrison Hong, Caroline Hoxby, Leigh Linden, Jim Poterba, Dorothy Robinson, Rik Sen, Michael Smith, Laura Starks, David Swensen, Jay Wang, Mike Weisbach, and Josef Zechner for useful comments and suggestions. We also thank Matt Hamill and Ken Redd of NACUBO and John Griswold of the Commonfund for assistance with data and helpful discussions. Andrew Edgar and Jia Xing provided excellent research assistance. The views expressed herein are those of the authors and not necessarily those of the National Bureau of Economic Research.

NBER working papers are circulated for discussion and comment purposes. They have not been peerreviewed or been subject to the review by the NBER Board of Directors that accompanies official NBER publications.

(C) 2010 by Jeffrey Brown, Stephen G. Dimmock, Jun-Koo Kang, and Scott Weisbenner. All rights reserved. Short sections of text, not to exceed two paragraphs, may be quoted without explicit permission provided that full credit, including $(\mathcal{C}$ notice, is given to the source. 
How University Endowments Respond to Financial Market Shocks: Evidence and Implications Jeffrey Brown, Stephen G. Dimmock, Jun-Koo Kang, and Scott Weisbenner

NBER Working Paper No. 15861

April 2010, Revised August 2012

JEL No. G01,G11,I22,L3

\begin{abstract}
$\underline{\text { ABSTRACT }}$
Endowment payouts have become an increasingly important component of universities' revenues in recent decades. We test two leading theories of endowment payouts: (1) universities smooth endowment payouts, or (2) universities use endowments as self-insurance against financial shocks. In contrast to both theories, endowments actively reduce payouts relative to their stated payout policies following negative, but not positive, shocks. This asymmetric behavior is consistent with "endowment hoarding," especially among endowments with values close to the benchmark value at the start of the university president's tenure. We also document the effect of negative endowment shocks on university operations, including personnel cuts.
\end{abstract}

\author{
Jeffrey Brown \\ Department of Finance \\ University of Illinois at Urbana-Champaign \\ 515 East Gregory Drive \\ Champaign, IL 61820 \\ and NBER \\ brownjr@illinois.edu \\ Stephen G. Dimmock \\ Division of Finance and Banking \\ Nanyang Technological University \\ Singapore, 639798 \\ dimmock@ntu.edu.sg
}

\author{
Jun-Koo Kang \\ Nanyang Technological University \\ Singapore \\ JKKANG@ntu.edu.sg \\ Scott Weisbenner \\ University of Illinois at Urbana-Champaign \\ Department of Finance \\ 340 Wohlers Hall, MC-706 \\ 1206 South Sixth Street \\ Champaign, IL 61820 \\ and NBER \\ weisbenn@illinois.edu
}


Endowments have become an increasingly important source of financing for universities over the past two decades, as the growth rate of the average endowment has far outpaced the growth rate of university expenditures. Much of this endowment growth is attributable to the positive investment returns that resulted from the gradual shift of endowment investments from fixed income to equities in the 1970s and 1980s, followed by a shift towards alternative assets such as hedge funds, private equity, and venture capital in the 1990s and 2000s (Lerner, Schoar, and Wang 2008). Although this shift provided endowments with impressive average returns, it also increased endowments' exposure to financial market risk, including the large market downturns witnessed in 2001-2002 (the bursting of the technology bubble) and 2008-2009 (the global financial crisis). This paper uses these financial market fluctuations to test alternative economic theories of endowment payout behavior.

Several of the leading minds of the economics profession have written normative models of university endowments that have implications for endowment payout policy. Tobin (1974) presents a model in which endowments smooth the income provided to the universities they support. Merton (1992) analyzes a portfolio choice model in which endowment payouts are one part of a university's overall revenue stream, and argues that endowments should be used to hedge shocks to other revenue sources. Black (1976) also emphasizes the idea of endowments as a form of self-insurance, noting that "it is important to see the endowment fund as just one of the university's sources of income." Despite this theoretical attention, the empirical literature on endowment payouts is surprisingly thin. We step into this void by analyzing the payout behavior of endowments, focusing specifically on how endowment payouts respond to both positive and negative financial shocks. Our empirical results are inconsistent with both of these theories as positive descriptions of endowment behavior.

To empirically document how endowments respond to shocks, we combine several sources of data into a panel that includes information on both endowments and their affiliated universities. We measure endowment shocks both by endowment returns as well as the returns normalized by endowment size relative to university total costs. To allow for asymmetric responses, we decompose endowment shocks into positive and negative shocks. Although endowments experienced considerable growth over our 1987 - 2009 sample period, they also experienced two severe negative financial shocks - the collapse of the technology bubble and the global financial crisis. 
Our panel data allow us to control for a rich set of covariates, including university fixed effects and state-by-year-by-public/private fixed effects. As such, we control directly for all time-invariant characteristics that might be unique to a given university (e.g., its location, history, prestige, etc.), as well as control for any factors that might differentially affect a given state, be specific to a given year, or even be specific to a given type of institution (public versus private) within a specific state within a specific year (e.g., economic and financial conditions or demand for certain types of universities that may vary both regionally and over time). Our identification therefore comes from studying different responses by universities of the same type (i.e., public or private), in the same state, and in the same year, to differences in the size of both positive and negative endowment shocks, while controlling for time-invariant differences across universities.

Our primary finding is that university endowments exhibit an asymmetric response to contemporaneous positive and negative financial shocks. Specifically, following positive shocks endowments tend to follow their own stated payout policies (e.g., pay out 5\% of the past threeyear average of endowment values). Whereas following contemporaneous negative shocks, many endowments actively deviate from their stated payout policies, actually reducing payout rates to a level below that implied by their standard smoothing rules. We also fail to find consistent evidence that universities change endowment payouts to offset shocks to other sources of university revenues. These findings, which we confirm through several robustness checks, suggest that endowments' behavior is inconsistent with either the "smoothing" or the "selfinsurance" hypotheses.

Given the rejection of these normative hypotheses, we turn to an alternative hypothesis, which we refer to as "endowment hoarding." This idea is captured succinctly by Hansmann (1990, p. 38) who argues that "maintenance of an endowment is often viewed as an objective in its own right, rather than as simply a means to an end." Similarly, Conti-Brown (2011, p. 704) speculates that university administrators limit payouts, even in bad economic times, because they value endowment size as a "symbol of status and prestige." Our core result regarding the asymmetry payout response to endowment shocks (i.e., reduced payouts following negative shocks, but no response to positive shocks) is, to our knowledge, the first careful empirical test

\footnotetext{
${ }^{1}$ This terminology is motivated by Senator Charles Grassley (R-Iowa), who has repeatedly accused university leaders of "hoarding assets". See http://www.insidehighered.com/news/2011/12/09/grassley-renews-focusendowments and http://www.grassley.senate.gov/news/Article.cfm?customel dataPageID 1502=38191.
} 
of the "endowment hoarding" hypothesis, and the results are supportive of this view. To further refine our test, we examine situations where the incentive to hoard assets would be particularly strong: we create a variable "president's benchmark", which is the ratio of the current endowment size to its size at the beginning of the president's tenure, the idea being that university leadership may be particularly sensitive to growing the size of the endowment from what they inherited. We find a sharp non-linearity in the response of payouts to endowment shocks: the asymmetric response to shocks is driven entirely by universities whose endowments are within $10 \%$ of the president's benchmark.

We then examine whether this payout behavior has real consequences for university operations. Although the link between financing decisions and real activities of corporations has long been considered an important research question, dating back to the work of Modigliani and Miller (1958), ours is the first study to provide evidence on how financial shocks to endowments affect universities. Given that universities do not fully smooth over negative shocks (and, indeed, do the opposite), we expect universities to adjust on some other margin. Consistent with this view, we find that these shocks indeed impact universities' real operations, namely, university employment. ${ }^{2}$ Specifically, we find that, relative to universities with smaller shocks, universities with larger negative endowment shocks respond, on average, by reducing tenuresystem faculty: a negative endowment shock that is equivalent to $10 \%$ of a university's budget leads to a $2.9 \%$ reduction in the number of tenure-system faculty during the year of the negative shock (either through less hiring, greater attrition, or more dismissals), with an additional 6.1\% reduction in the following year. In contrast, we do not observe any changes in the number of faculty following positive shocks. In addition to reducing tenure-system faculty, universities react to negative shocks by cutting support employees (e.g., secretaries) and maintenance employees to a similar extent. We find no effect, however, on the number of adjunct faculty or administrators. Consistent with the results for payouts, the effects of negative endowment shocks on staffing are concentrated among universities whose endowments are close to the president's benchmark value, as these are precisely the universities that experience the largest endowment payout reductions.

\footnotetext{
${ }^{2}$ Focusing on university employment decisions has several advantages. First, salaries and benefits to university employees are sizeable, representing roughly $60 \%$ of the typical doctoral university's budget. Second, the classifications and counts of university employees are measured consistently across universities and within a given university over time, enabling valid cross-sectional and time-series comparisons.
} 
Understanding the real effects of endowment behavior is important for several reasons. At a broad level, universities serve as a major source of knowledge creation and dissemination and thus contribute to the global stock of human capital. Our research contributes to the understanding of whether financial markets have an effect on these educational activities and thus provides evidence on a channel through which financial markets can influence the real economy in important and long-lasting ways. At a more personal level, many of the readers of this paper will likely be scholars employed by U.S. doctoral institutions, and the effect of endowment shocks has the potential to influence our profession in a very direct way. In addition to endowment shocks, our study may also provide insight into how universities respond to other types of financial shocks, such as shocks to public funding or changes in gifts, grants, and contracts. The advantage of using endowments to identify a university's response to resource shocks is that these shocks are largely exogenous, as the variation arises from historical differences in activities to build and invest an endowment combined with fluctuations in global financial markets. In contrast, other types of variation in a university's resource base might be endogenously determined. Finally, our results have implications for the current policy debate about the proper role and payout policies of endowment funds.

The paper proceeds as follow. Section 1 provides an overview of university endowments, their payout policies, and their recent growth. Section 2 reviews the economic theories of endowment payouts, highlights the empirical implications of these theories, and discusses testable hypotheses. Section 3 discusses our research methodology. Section 4 presents the core results, and the robustness tests that rule out alternative explanations such as legal constraints on spending. Section 5 tests the endowment hoarding hypothesis, that payout decisions are influenced by a desire to grow the endowment, especially relative to the endowment's value at the start of a university president's tenure. Section 6 provides evidence on how these payout responses affect universities' real operations, specifically personnel decisions. Section 7 concludes.

\section{An Overview of University Endowments}

\subsection{What is an Endowment?}

Endowments consist of both financial and real assets held to generate income for current and future operations of their affiliated universities (Ehrenberg 2009). Typically, the size of the 
endowment reported by a university consists of both "true endowments" (assets specified by the donor to be held in perpetuity) as well as "quasi-endowments" (funds the university treats as an endowment but which could be spent should the university so choose). ${ }^{3}$

Although endowments are usually separate legal entities from the universities they serve, endowment boards are typically appointed by the university. Indeed, most endowment board members are also university trustees. Endowment boards typically delegate the selection of investment managers to the endowment board's investment committee, but in the majority of cases the university retains direct control over spending rates. Even when authority for spending is formally granted to the investment committee, as is the case for approximately $38 \%$ of endowments, anecdotal evidence suggests that university leadership has enormous influence over those decisions that directly influence resource allocation to the university. Indeed, in more than two-thirds of endowments, the university president sits on the investment committee. In more than three-quarters of endowments, the president, the CFO (who reports to the president), or both serve on the investment committee. As such, it is generally believed that university presidents have substantial influence over payout decisions. ${ }^{4}$

\subsection{Endowment Payout Policies and Payout Rates}

Unlike private foundations, which are required by law to make minimum payouts each year, university endowments are not subject to such restrictions. Nonetheless, nearly all university endowments follow payout policies that distribute money to support the educational mission of their affiliated university. The typical endowment spending policy specifies a payout rate that is applied to a multi-year moving average of endowment values. For example, an endowment's spending policy might specify that it spends $5 \%$ of a three-year moving average of its endowment balance. This rule has the effect of partially smoothing payout levels as the endowment size changes over time.

When discussing payout rates, it is useful to distinguish the rate specified in the endowment's spending policy and applied to a moving average of prior years' endowment values, from the payout rate defined as actual dollar payouts relative to the contemporaneous endowment value. To help distinguish these two different concepts of payout rates, we use the

\footnotetext{
${ }^{3}$ Hansmann (1990) and Dimmock (2012) use the term "quasi-endowment," whereas Ehrenberg (2009) uses the term "funds functioning as endowments."

${ }^{4}$ See Brown, Dimmock, Kang, Richardson, and Weisbenner (2011) for further details on endowment governance.
} 
terms "policy payout rate" and "payout rate." A simple example is useful for illustrating this distinction: Suppose an endowment has a value of $\$ 70$ million at the start of year $t-2$, experiences net growth of $\$ 10$ million per year for the next three years (where net growth includes new donations and returns on existing balances, minus payouts to the university), followed by a substantial loss of $\$ 20$ million during year $t+1$, and no net growth in year $t+2$. The chart below illustrates how payout amounts would follow these endowment values assuming the endowment follows a policy of paying out $5 \%$ of a past 3 -year moving average.

\begin{tabular}{|l|c|c|c|c|c|c|}
\hline & $t-2$ & $t-1$ & $t$ & $t+1$ & $t+2$ & $t+3$ \\
\hline $\begin{array}{l}\text { Endowment Value } \\
\text { (beginning of year) }\end{array}$ & $\$ 70$ & $\$ 80$ & $\$ 90$ & $\$ 100$ & $\$ 80$ & $\$ 80$ \\
\hline $\begin{array}{l}\text { Net Growth in Endowment } \\
\text { (during year) }\end{array}$ & $\$ 10$ & $\$ 10$ & $\$ 10$ & $-\$ 20$ & $\$ 0$ & - \\
\hline $\begin{array}{l}\text { Payout Amount } \\
\text { (during year) }\end{array}$ & - & - & $\$ 4.0$ & $\$ 4.5$ & $\$ 4.5$ & $\$ 4.3$ \\
\hline $\begin{array}{l}\text { "Policy Payout Rate" } \\
\text { (payout amount divided by past 3- } \\
\text { year average endowment value) }\end{array}$ & - & - & $5.0 \%$ & $5.0 \%$ & $5.0 \%$ & $5.0 \%$ \\
\hline $\begin{array}{l}\text { "Payout Rate" } \\
\text { (payout amount divided by } \\
\text { current year endowment value) }\end{array}$ & - & - & $4.4 \%$ & $4.5 \%$ & $5.6 \%$ & $5.4 \%$ \\
\hline
\end{tabular}

This example illustrates the inherent smoothing effect of multi-year averaging payout rules. While the "policy payout rate" is constant at 5\% as specified by the payout rule, the contemporaneous "payout rate" is below $5 \%$ in rising markets and above $5 \%$ in falling markets. Because the policy payout rate is defined based on historical endowment values, financial shocks during the year should not affect payout amounts during that year. Rather, a shock this year will affect future payouts through the moving average formula. Whether endowments adhere to their stated payout policies is an important focus of our empirical work, and we will return to these ideas in Section 2 below.

\subsection{Data on Endowments and Universities}

The best available source of data on university endowments is the series of annual surveys conducted on behalf of the National Association of College and University Business Officers (NACUBO). These data have been used in several studies of endowment investment behavior, including Lerner, Schoar, and Wang (2008), Brown, Garlappi, and Tiu (2010), Barber 
and Wang (2011), and Dimmock (2012). These data cover the period from 1986 through $2009^{5}$ (where 1986 and 2009 refer to the 1985-86 and 2008-09 academic years, respectively) and provide information on the market value of the endowment, investment performance, payout rates, as well as other information. ${ }^{6}$ For a more detailed description of the NACUBO data, we refer the reader to Brown, Garlappi, and Tiu (2010).

We are also interested in characteristics of the universities that the endowments support. Thus, we merge the NACUBO data with data from the Integrated Postsecondary Education Data System (IPEDS), collected by the National Center for Educational Statistics (a division of the U.S. Department of Education). These data include extremely rich information on nearly every aspect of universities, including numbers of employees by job category. ${ }^{7}$

For some of our analysis, we also use information from the Commonfund endowment surveys. The Commonfund is a non-profit organization whose stated mission is to "enhance the financial resources of nonprofit institutions and to help them improve investment management practices." ${ }^{8}$ The Commonfund surveys provide more detailed information about the specific payout policies for a subset of the institutions in the NACUBO sample.

To examine how endowments respond to shocks, we focus on universities with the Carnegie Classification of "doctoral" (i.e., universities that offer Ph.D. degrees) ${ }^{9}$ for three reasons. First, endowments tend to be relatively more important for these institutions than for other colleges and universities (the obvious exception being a small set of prestigious liberal arts colleges). Second, doctoral institutions are a more homogeneous group than all colleges and universities, thus allowing us to more cleanly focus on the effect of endowment shocks. Finally, more reliable and longer time-series data are available for doctoral institutions than for institutions with other Carnegie classifications. ${ }^{10}$

\footnotetext{
${ }^{5}$ In 2009, NACUBO merged its endowment survey with the Commonfund's endowment survey. The data for the 2008-2009 academic year comes from the joint NACUBO-Commonfund Endowment Survey (NCES). For expositional simplicity, we refer to this merged datasets as the NACUBO data set throughout the paper.

${ }^{6}$ Since our regression analysis controls for lagged values of the independent variables, 1988 is the first year used.

${ }^{7}$ Coverage in the dataset differs by variable. The numbers of employees by job category are available throughout the sample except for the years 1988, 1990, and 2000. Endowment payouts are available from 1993 onward. Endowment size, endowment returns, and total university costs are available over the full sample period.

${ }^{8}$ See http://www.commonfund.org/Commonfund/About+Us/commonfund_mission_2004.

${ }^{9}$ For more information on Carnegie Classifications, see http://classifications.carnegiefoundation.org/.

${ }^{10}$ Most doctoral universities participate in the NACUBO endowment survey for the entire period. In contrast, nondoctoral institutions generally entered the sample more recently.
} 
In 2008, there were just over 200 U.S. doctoral universities with endowment data available through the NACUBO surveys. This sample accounts for $80 \%$ of all doctoral institutions, $94 \%$ of total spending, $90 \%$ of students, and $99.9 \%$ of federal research spending of the entire universe of U.S. doctoral institutions. Throughout the paper, for expositional purposes, we use the term "universities" to refer to doctoral universities.

\subsection{The Size, Growth, and Volatility of University Endowments}

In Table 1, we report summary statistics for our sample of institutions from the 1985-86 academic year through the 2008-09 academic year. As shown in the first row of Table 1, endowment size varies tremendously, with the mean endowment size of nearly $\$ 740$ million being significantly larger than the median of $\$ 193$ million. The largest endowment in the sample is Harvard University, with a June 2008 value of more than $\$ 43$ billion.

In the second row of Table 1, we report the distribution of the endowment-to-cost ratio (endowment market value normalized by annual university budget) for all doctoral institutions. This ratio measures the importance of the endowment to university operations, and we again see tremendous heterogeneity. The mean ratio is approximately 1 , suggesting that a $10 \%$ change in the size of the endowment is of comparable magnitude, on average, as a one-time, $10 \%$ shock to a university's spending.

As illustrated in Figure 1, the aggregate value of the endowments held by U.S. doctoral universities has increased tremendously over the past two decades, growing to $\$ 370$ billion in 2008 from $\$ 31$ billion in 1986, before declining to $\$ 273$ billion in 2009 as a result of the global financial crisis. In Figure 2, we compare the growth in endowment values over our sample period with that of university budgets. In the top chart, we simply plot the growth rates of the average endowment value and average annual university budget. In the bottom chart, we plot the growth rates of the median values of these two variables. The annual growth rate for the average (median) endowment is $8.7 \%$ (8.3\%) over 1986-2009, outpacing the growth rate for the average (median) university budget of $6.4 \%$ (5.7\%).

Although our sample period was dominated by rising equity markets, it was not immune from negative shocks. The recent drop in endowment values is quite substantial in both dollar amounts and percentage terms; however, it appears somewhat less drastic when placed in historical perspective. For example, as a result of the recent market declines, endowments, on 
average, returned to their level of about three years earlier (i.e., 2006). Thus, the extent to which universities felt the pain of the recent declines depends, in part, on how quickly they incorporated prior endowment gains into their payout decisions.

Turning to Table 1, we find that payout rates (the amount of money transferred from the endowment to the university in a given year normalized by the market value of the endowment at the start of the year) are generally between 4-5\%. For the full sample, endowment payouts cover about $5 \%$ of a university's total costs, with endowments accounting for at least $12 \%$ of the annual budget at one-tenth of universities. The average annual endowment return is $9.0 \%$ over the full sample period, with a two-year average cumulative return over the 2001 and 2002 academic years of $-9.2 \%$, and an average return of $-19.7 \%$ over the $2008-9$ academic year. Figure 3 illustrates both the time-series and cross-sectional variation in the performance of endowments over the full sample period.

Table 1 also shows that, not surprisingly, the main component of university expenditures is payment to employees: salaries and benefits account for $58 \%$ of the average university budget for the full sample; with a tight distribution across universities (the $10^{\text {th }}$ percentile budget share is $42 \%$ and the $90^{\text {th }}$ percentile budget share is $65 \%$ ). The average (median) number of full-time employees is 4,892 $(3,897)$. Tenure-system faculty account for just over one-quarter of the workforce of a typical university, with support employees (e.g., secretaries) accounting for just under half of all full-time employees. ${ }^{11}$

\section{Theories of Endowments and Testable Hypotheses}

\subsection{Theories of Endowments}

As noted by Hansmann (1990), Winston (1999), and others, the theory of the non-profit sector in general, and higher education in particular, is not as well-developed as standard producer or consumer theory. Indeed, there is no consensus view in the literature on how to define the objective functions of universities or the endowments that help to support them. ${ }^{12}$

\footnotetext{
${ }^{11}$ The number of employees is measured at the end of the academic year (e.g., the 2009 number of employees reflects the head count as of June 30, 2009).

${ }^{12}$ Winston (1999) summarizes a number of ideas relating to universities' objective functions, including Clotfelter's (1999) suggestion that universities are motivated by “the pursuit of excellence," Bowen and Breneman's (1993) notion that universities seek to improve the quality and equity of educational services, and James (1990) idea of "prestige maximization."
} 
This lack of consensus is not due to a lack of attention, as several leading economists have proposed normative models of endowment behavior.

The first theory of endowments comes from Tobin (1974) who argues that the trustees of an endowed institution should act as if the institution is immortal and seek to treat all generations equally. Thus, his model suggests that the trustees should behave as if they have a zero subjective rate of time preference. He further argues that current consumption should not benefit from the prospect of future gifts to the endowment, nor should changes in tuition, grants, or other revenue affect payouts. The main implication of his model is that endowments should provide a smooth flow of real income to their affiliated universities. In summarizing the early literature on endowment payouts, ${ }^{13}$ Merton (1992) states that all of the early models take "as given that the objective for an endowment is to provide a perpetual level flow of expected real income."

Tobin's (1974) “smoothing” model has two important empirical implications. First, the short-term payout response to shocks should be small, because endowments should spread the gains and losses over time. In the extreme, if a university's endowment engages in complete smoothing over an infinite life, endowments should respond to permanent shocks by adjusting payout levels by the perpetuity value of the shock. Second, endowments should respond symmetrically to positive and negative shocks; that is, their responses to positive and negative shocks should be of equal magnitude.

The second theory of endowments is that they provide universities with the ability to selfinsure, such as allocating assets to hedge against revenue shocks or using the endowment as a form of precautionary savings that can be tapped when other revenues are unexpectedly low. Hansmann (1990) argues that one of the most compelling reasons to accumulate endowments is that "they serve as a financial buffer against periods of financial adversity." 14 This idea is discussed in the context of asset allocation by Black (1976) and Merton (1992). In the case of complete markets, Merton (1992) shows that asset allocation can allow endowments to perfectly hedge against shocks to other revenues. In incomplete markets, however, Merton (1992) shows

\footnotetext{
${ }^{13}$ Merton's (1992) review includes papers by Eisner (1974), Litvack, Malkiel, and Quandt (1974), and Nichols (1974), among others. For a more recent contribution to this literature, see Gilbert and Hrdlicka (2011).

${ }^{14}$ Hansmann (1990) also explains several other compelling reasons to hold endowments: "to insure the long-run survival of the institution's reputational capital, they protect the institution's intellectual freedom, and they assist in passing on values prized by the present generation." He goes on to question whether endowments are really managed in a manner that is consistent with these goals and suggests that "prevailing endowment spending rules seem inconsistent with most of these objectives" (p. 39). However, he does not provide any rigorous empirical tests to support these arguments, and his conclusions have been criticized by Swensen (2000, p. 43-50), among others.
} 
that universities should adjust contemporaneous payout rates in response to both endowment shocks and other revenue shocks. Thus a key role for endowment payouts may be to smooth out the effects of temporary shocks. Alternatively, if rapid adjustments are costly, endowments may provide valuable liquidity in the face of permanent shocks, reducing the total adjustment costs for universities (e.g., by allowing a university to reduce tenured faculty through attrition rather than by eliminating an entire department). To the extent that endowments serve as rainy day funds, either for endowment shocks or for other revenue shocks, we might expect endowment managers to be very conservative in their payouts during rising markets, thus engaging in precautionary saving, but then spend more aggressively during bad times. This argument would imply an asymmetric response to shocks, with endowments slowly adjusting spending following positive shocks, but quickly increasing spending following negative shocks.

\subsection{Testable Hypotheses}

We test these theories of endowments by focusing on how endowments adjust payout amounts in response to contemporaneous and lagged shocks and whether the direction of any endowment payout response is symmetric with respect to positive and negative shocks.

The vast majority of university endowments use a spending policy that calculates payout amounts as a fraction of an average of past endowment market values. These policies can be viewed as an imperfect attempt to implement the Tobin (1974) smoothing model, as past shocks are gradually incorporated into payout decisions over several years. Further, because these payout policies are based on past endowment values (Sedlacek and Jarvis 2010), they imply that there should be no relation between contemporaneous financial shocks and endowment payouts. Rather, payout rates should respond to endowment shocks with a lag. As such, a finding that endowment shocks have little relation with contemporaneous payout rates, and that any relation is symmetric, would be consistent with the Tobin model. The Tobin model further implies that there should be no relation between other revenue shocks and endowment payout rates.

In contrast, the Black/Merton "self-insurance" model implies an asymmetric response to positive and negative shocks. Following negative revenue shocks, endowments should increase contemporaneous payout rates. Essentially, universities make insurance claims on their endowments in bad states of the world when additional payouts are more valuable. Following positive revenue shocks, endowments should either decrease or maintain their payout rates. The 
self-insurance model is less clear regarding the effect of endowment shocks. In the formal model of Merton (1992), payout rates should respond symmetrically to positive and negative shocks. In the next section, we will set forth our econometric specification, and restate these hypotheses in terms of the key coefficients in the model.

\section{Methodology}

\subsection{Defining Shocks}

To test these hypotheses, we examine how endowment payouts respond to endowment shocks. We begin by simply regressing the natural log of payouts on endowment returns during the year (and a range of fixed effects). We then examine how contemporaneous payout rates are affected by endowment shocks, which we measure by normalizing endowment returns by the endowment fund size relative to the university's expenditures in year t-1.

Specifically, we define endowment shocks as:

$$
\text { Shock }_{i, t}=\text { Return }_{i, t} \times \frac{\text { Endow mentFundSize }_{i, t-1}}{\text { Total University Costs }}
$$

where subscript $i$ denotes the university and subscript $t$ denotes the academic year.

Our measure of endowment shocks is meant to capture the intuitive notion that a university with a large endowment-to-cost ratio may be more responsive to endowment returns than a university with a small ratio. For example, a university that relies on endowment income to cover the majority of its costs may respond to a given percentage return differently than a university whose endowment covers a trivial share of its costs. In essence, our measure captures the variation in the "shock" that comes from both the endowment's return and its size relative to university costs. One can also think of the shock variable as the ratio of the change in the dollar value of the endowment to the dollar flow of university expenditures.

Figure 4 illustrates both the time-series and cross-sectional variation in the shock variable from 1986 to 2009. Over our sample period, as shown in Table 1, the average endowment shock to a university was a positive 0.09 , suggesting that the average financial shock to the endowment represents $9 \%$ of the university's total costs. Most universities suffered through two years of negative endowment shocks over the period 2001-2002. For example, in 2002, the average endowment shock was -0.054 (i.e., a shock equivalent to a $5.4 \%$ cut in the budget), with onequarter of universities having a shock worse than -0.076 and one-tenth having a shock worse 
than -0.127 . Of course, the 2008-09 shock corresponding to the global financial crisis was more pronounced, with even performers at the $90^{\text {th }}$ percentile experiencing a negative shock.

As discussed in Section 2, the key to empirically testing the smoothing and self-insurance models is to separately examine how endowments respond to positive and negative shocks, and whether they respond contemporaneously or only with a lag (as expected from their smoothing rules). In order to test for possible asymmetric responses to positive and negative shocks, we decompose the Shock variable into two components:

$$
\begin{aligned}
& \text { Shock }_{i, t}^{+}=\operatorname{Max}\left[0, \quad \operatorname{Return}_{i, t} \times \frac{\text { Endow mentFund Size }_{i, t-1}}{\text { Total University } \operatorname{Costs}_{i, t-1}}\right] \\
& \operatorname{Shock}_{i, t}^{-}=\operatorname{Min}\left[0, \quad \operatorname{Return}_{i, t} \times \frac{\text { Endow mentFund Size }_{i, t-1}}{\text { Total University Costs }} \mathrm{C}_{i, t-1}\right]
\end{aligned}
$$

Further, we include both contemporaneous and one-year-lagged values of these variables in our regressions.

Similarly, we create revenue shock variables to measure shocks to a university's nonendowment revenues. The revenue shock variables are calculated using revenues from government appropriations (from federal, state, and local governments) and government gifts, grants and contracts (e.g., research funding through agencies such as NSF and NIH) received by the university. In Table 1, we provide summary statistics for the fraction of university costs financed by different revenue sources. ${ }^{15}$ We do not include some major sources of revenue, such as tuition or current-use donations, because universities have a relatively large degree of control over these revenue sources. Note that if we include all revenue sources when constructing our revenue shock variables, the results are essentially unchanged.

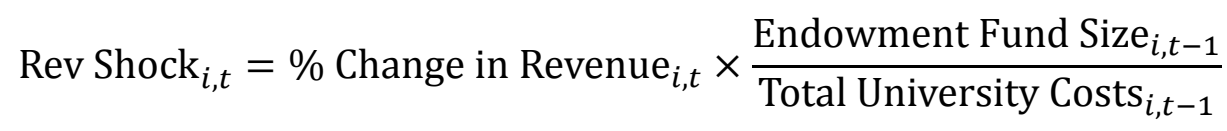

Again, we decompose the revenue shock variable into positive and negative shocks, and include both contemporaneous and one-year-lagged values in all regressions.

\footnotetext{
${ }^{15}$ The share of university costs financed by these three revenue sources plus endowment payouts is on average less than 1.0 because universities receive revenue from other sources such as hospitals.
} 


\subsection{Estimation and Identification}

We use the endowment and revenue shock variables to test how endowments respond to these economic shocks. Our baseline specification is:

$$
\begin{aligned}
\text { Dependent } \operatorname{Var}_{i, t} & =\beta_{1} \cdot \operatorname{Shock}_{i, t}^{+}+\beta_{2} \cdot \operatorname{Shock}_{i, t}^{-}+\beta_{3} \cdot \operatorname{Shock}_{i, t-1}^{+}+\beta_{4} \cdot \operatorname{Shock}_{i, t-1}^{-} \\
& +\gamma_{1} \cdot \operatorname{Rev} \operatorname{Shock}_{i, t}^{+}+\gamma_{2} \cdot \operatorname{Rev} \operatorname{Shock}_{i, t}^{-} \\
& +\gamma_{3} \cdot \operatorname{Rev} \operatorname{Shock}_{i, t-1}^{+}+\gamma_{4} \cdot \operatorname{Rev} \operatorname{Shock}_{i, t-1}^{-} \\
& +v_{i}+\lambda_{\text {state } \times \text { year } \times \text { private }}+\varepsilon_{i, t}
\end{aligned}
$$

The dependent variable in our main specification is the contemporaneous payout rate. We briefly explain the fixed effects strategy used in these regressions, and then turn to the independent variables of interest and recast the testable hypotheses from Section 2.2 in terms of these coefficients.

The symbol $v$ signifies the inclusion of a complete set of university fixed effects, and $\lambda$ represents a complete set of state-by-year-by-private fixed effects (where "private" distinguishes private from public universities). The inclusion of university fixed effects means that we compare differences in the dependent variable to differences in the shocks. Thus, any differences in the dependent variable driven by time-invariant characteristic of a university (e.g., history, geography, composition of alumni base, etc.) are differenced out of the specification. Furthermore, these fixed effects control for differences between public and private universities such as in their sources of funding, administrative models, or political pressures; differences across states; differences over time, and all interactions between these three factors (which control for, among many things, time-varying regional differences in economic conditions).

Given this rich set of controls, the primary source of variation that is used to identify the effect of shocks on payout rates and university employment arises from differences in two public (or two private) institutions within the same state in the same year. For example, we are implicitly comparing how changes over time in the shocks faced by UCLA differ from shocks faced by UC-Berkeley, or how shocks faced by Northwestern University differ from shocks faced by the University of Chicago.

Having explained the fixed effects used in the empirical tests, we discuss the predicted signs and magnitudes of the coefficients on the shock variables implied by the theories outlined in the previous section. If the Tobin (1974) model is taken literally, it predicts that all coefficients should equal zero, both for the endowment shocks and for the revenue shocks. A 
less strict interpretation of the model might consider the effect of the smoothing rules used by endowments to set their payout rates. In this case, it could be the case that $\beta_{3}=\beta_{4} \geq 0$; all other coefficients would remain zero, even in this case.

In contrast, the Black/Merton self-insurance model predicts that endowments will increase contemporaneous payout rates in response to negative shocks, and either maintain or reduce payouts following positive shocks. This implies that $\beta_{2} \leq \beta_{1} \leq 0$ and $\beta_{4}<\beta_{3} \leq 0$, and similarly for the revenue shocks $\gamma_{2} \leq \gamma_{1} \leq 0$ and $\gamma_{4}<\gamma_{3} \leq 0$.

We include revenue shock variables as a test of the self-insurance hypothesis. Although we limit our revenue shock variables to include only revenue sources over which the university does not have direct control (e.g., from the government), we acknowledge that these other revenue shocks might be endogenously determined, such as if a state legislature changed funding in response to university spending. Endogeneity, however, would bias our tests towards finding significant results for the revenue shock variables; we do not find significant results. Another concern with the possible endogeneity of the revenue shock variables is that their inclusion could bias our results for endowment shocks. Thus we include specifications both with and without the revenue shocks. In all of our regressions, the inclusion of these other revenue shock variables does not significantly alter the coefficient estimates on the endowment shock variables.

We also separately examine a subset of 69 university endowments covered in the Commonfund data over the period 2000-2009, for which we can precisely measure the exact trailing percentage rate applied to these lagged values. ${ }^{16}$ For this subset of institutions, we analyze the extent to which the endowments deviate from their own payout policies and "actively manage" payouts to the universities.

\section{How Do Endowment Payouts Respond to Endowment Shocks?}

Before turning to the main specification outlined above, we begin by simply regressing the log of dollar payouts from endowments on endowment returns. In column (1) of Table 2, we estimate a model that includes university and year fixed effects. We find that, on average, if an endowment experiences a return of $+10 \%(-10 \%)$, it responds by increasing (decreasing) payouts in the current year by $2.7 \%$. This coefficient estimate is significant at the $5 \%$ level, rejecting the

\footnotetext{
${ }^{16}$ We limit our sample to university endowments whose payout policies are based on a moving average of prior endof-year endowment asset values, as we can calculate the precise amount of expected payouts for these endowments. We do not consider universities that base payouts on a moving average of past quarterly endowment values, because NACUBO only reports end-of-year endowment values.
} 
null hypothesis that endowment payouts are insensitive to contemporaneous returns. Thus these results are not consistent with what would be expected if endowments abided by their payout policies, which determine payouts as a function of a moving average of past endowment values.

However, as shown in column (2), this average response masks a substantial and important asymmetry in payout responses. We find that, as would be expected if endowments followed their own payout rules, the response to positive endowment returns is not significantly different from zero. In sharp contrast, the response to negative endowment returns is economically large and statistically significant. The coefficient estimate of 0.81 implies that a $10 \%$ negative endowment return is associated with an $8.1 \%$ reduction in payouts, an effect that is significantly different from the effect of a $10 \%$ positive endowment return on payouts. To put things in perspective, this result implies that given the average payout rate of $5.2 \%$ in our sample (Table 1), a contemporaneous negative return of $10 \%$ reduces payouts by approximately 0.42 percentage points $(=0.1 * 0.8 * 5.2){ }^{17}$

In columns (3) and (4) of Table 2, we add state-by-year-by-private fixed effects in addition to university and year fixed effects. This additional control allows us to measure the effect of endowment returns on payouts by comparing two public (or two private) institutions in the same state and in the same year. It also allows us to control for a wide range of time varying factors that might otherwise spuriously drive the relation, such as state-specific economic trends or changes in state support for higher education. We find a small increase in payouts following positive returns: a $10 \%$ positive return would increase payouts by $3 \%$, or an increase in payout rates of 0.16 percentage points from an average $5.2 \%$ payout rate. The effect of a negative return remains significantly larger, with a coefficient estimate of 1.08 , suggesting that a $10 \%$ negative return leads endowments to actively reduce payout rates by $10.8 \%$, or by approximately 0.56 percentage points relative to the average payout rate. Thus, this regression analysis highlights a striking asymmetry in endowment payout policy.

\footnotetext{
${ }^{17}$ We stress that in our empirical analysis, a finding that universities "reduce" their payout rates in response to a negative return means that their payout amounts and payout rates are lower than what one would expect based their on payout policies. Of course, this does not necessarily imply that the payout rates decline relative to the prior year. The payout rates could rise relative to prior years (as is typically the case when endowments fall in value), but if managers actively reduce their payout amounts below those implied by their rule, the payout rates will rise by less than one would expect from the application of the payout policies. In the numerical example discussed in Section 1.2 , if an endowment's payout rate was $5.2 \%$ in year $t+2$, instead of the $5.6 \%$ implied by their smoothing policy, this would still be an increase from the $4.5 \%$ payout rate of the prior year. However, the $5.2 \%$ payout rate would represent a cut in the payout rate relative to that implied by the endowment's payout policy. In our discussion, we will refer to this deviation as a "reduction" in payouts.
} 


\subsection{Endowment Shocks and Payout Rates}

As noted previously, the proportion of the total university budget funded from the endowment varies widely across universities. Thus, in Table 3 we turn to an independent variable that weights endowment returns by the ratio of the endowment size to total university costs: the Shock variable defined in the previous section.

In all columns of Table 3, we report the coefficient estimates from regressions of the endowment payout rate over the period 1993-2009 on our measures of contemporaneous positive and negative shocks. The payout rate is defined as payouts made by the endowment to the university during the year divided by the endowment market value at the start of the year, and is expressed in percentage points. All columns include university fixed effects as well as state-byyear-by-private fixed effects. In columns (2) and (3), we also include one-year lagged positive and negative shocks. In column (3), we further control for contemporaneous and lagged shocks to other revenues.

Across all three specifications, we find an asymmetric response to contemporaneous endowment shocks. Specifically, when an endowment experiences a negative shock during the year equal to $10 \%$ of the university's budget (i.e., Shock $_{i, t}^{-}=-0.10$ ), the payout rate for the average endowment falls by a highly significant $17-19$ basis points. As we discussed earlier, these results do not necessarily imply that payout rates decline in absolute terms. Rather, they indicate that after conditioning out the average level of changes in payout rates for comparable universities, universities with larger negative shocks have relatively lower payout rates. Put differently, universities that experience larger negative shocks have lower payout rates than one would expect. In contrast, when an endowment experiences a positive shock during the year equal to $10 \%$ of the university's budget (i.e., Shock $k_{i, t}^{+}=-0.10$ ), payouts from the average endowment are little changed.

In column (3), we also test whether shocks to other revenue sources are related to endowment payouts. The coefficients for the contemporaneous and lagged revenue shocks variables not jointly significant ( $\mathrm{p}$-value $=0.490$ ), while the endowment shocks are jointly highly significant (p-value (0.005). The negative coefficient on $\operatorname{Rev} \operatorname{Shock}_{i, t-1}^{-}$is directionally consistent with the self-insurance hypothesis, although the effect is only weakly significant and neither the magnitude of the coefficient nor its significance are consistent across alternative 
specifications in our robustness tests. Importantly, the inclusion of these variables does not affect our central result regarding the relation between endowment payout rates and endowment shocks; the effect of endowment shocks on endowment payouts is independent of the effect of other revenue shocks.

It is also important to note that our rich set of institutional and state-by-year-by-private fixed effects controls for many changes in expectations. Specifically, any change in expectations during any year for each group of universities from the same state and of the same type (i.e., public or private) will be accounted for by our fixed effects. For example, changing expectations about government funding (whether it be state appropriations for public universities or federal funding for research grants) or changing expectations about asset returns are largely captured by state-by-year-by-private fixed effects.

Indeed, for changing expectations to have any material effect on our results, they would have to be correlated with the size of endowment shocks. In other words, it is not enough for a university to change its future expectations as a result of an endowment shock, but rather it must be the case that institutions that experience larger shocks make larger changes in their expectations (controlling for the change in expectations during the year common to all universities from the same state and of the same type). To partially address this possibility, we test whether endowment payouts are related to the amount of life-income gifts held by the endowment. ${ }^{18}$ In exchange for making a life-income gift, the beneficiary receives an annuity. The endowment "owns" and invests these gifts, but payouts to the university cannot be made from them until the beneficiary dies, and life-income gifts are not included in the reported endowment size. Nonetheless, a university with a larger amount of life-income gifts can expect to have a larger endowment in the future. ${ }^{19}$ Thus, we test whether the anticipation of the larger future endowment resulting from these life-income gifts affects the payout rate from the endowment today. We find that this is not the case: interaction terms between the endowment shock variables and the ratio of life-income-gifts-to-endowment-size are not significant, and their inclusion in the regression leaves the coefficient estimate on the contemporaneous negative shock essentially unchanged.

\footnotetext{
18 These results are available upon request.

${ }^{19}$ Across all doctoral universities in 2008, the ratio of life-income gifts to endowment size averaged 0.10 (with this ratio exceeding 0.19 at one-tenth of universities).
} 


\subsection{Endowment Shocks and Deviations from Payout Policies}

Although our fixed effects strategy should control for any unobserved differences in payout policies, we can further alleviate this concern by re-estimating the regressions in Table 3 using the subset of university endowments for which we have sufficient information about their payout policies from the Commonfund data. These analyses appear in columns (1) through (3) of Table 4. As our dependent variable, we use the difference between actual payout rates and the hypothetical payout rates that would arise from a strict application of the endowment payout policies, expressed in percentage points. We find an even stronger asymmetric response: a 10\% negative shock reduces payouts by 47 to 57 basis points, whereas the coefficient for positive shocks remains small in magnitude and insignificantly different from zero.

\subsection{Robustness: Ruling out External Constraints on Payouts}

The interpretation of our findings depends critically on whether the cut in payouts is a choice, rather than the result of external constraints. An important legal constraint on endowment payouts is the Uniform Management of Institutional Funds Act (UMIFA), which historically placed restrictions on the payouts of endowments. ${ }^{20}$ UMIFA's restrictions on the payouts of endowments are well described in Gary (2004): "although variations exist, the general principles of UMIFA have been adopted almost universally ... UMIFA created the concept of 'historic dollar value' and then permitted the expenditure of appreciation in excess of historic dollar value if the institution determined that expenditure of the funds was prudent. Historic dollar value was determined based on contributions to the endowment fund. Income, appreciation and depreciation of assets did not affect historic dollar value." Given this restriction against spending the endowment below its historic dollar value, it is possible that universities found themselves constrained by UMIFA following negative endowment shocks. For example, if a shock reduced the endowment value below the historical dollar value, then the university would be constrained to reduce expenditures in order to abide by the limits. Such restrictions are typically applied on a gift-by-gift basis. Indeed, even in the absence of UMIFA, donors themselves could impose constraints against spending the principal, either explicitly (e.g., in donor agreements) or implicitly (e.g., by placing pressure on endowment managers).

\footnotetext{
${ }^{20}$ UMIFA was promulgated by the National Conference of Commissioners on Uniform State Laws in 1972.
} 
We perform additional specification tests, reported in columns (4)-(6) of Table 4, to ensure that such constraints cannot explain our results, even during the 2001-2002 negative endowment shocks when these constraints were more likely to bind. ${ }^{21}$ To account for the possibility that in a particular year, a cohort of gifts may be underwater, and thus unavailable for payouts, we re-estimate the payout rate regressions presented in Table 3. Using historical endowment data on annual donations and annual returns, we recreate the implied level of payouts that an endowment would make if it followed its payout policies and accounted for UMIFA restrictions under the following three assumptions: (1) the eligibility of each year's gifts for inclusion in the imputed payouts is determined at the start of the academic year; (2) partial inclusion of a cohort of gifts is possible, i.e., if a given year's gifts were valued at $103 \%$ of the original donation value, then up to $3 \%$ could be paid out from these gifts; (3) all donations given prior to 1998 were sufficiently above water that UMIFA was not binding (this assumption, which is made because of data limitations on historical donations, is unlikely to be problematic because returns prior to 1998 were sufficiently high that these gifts were unlikely to be underwater even after the technology bubble burst). Accounting for these UMIFA restrictions on endowment payouts has virtually no effect on our key results. Further casting doubt on the likelihood that our results are driven by external constraints is the fact that a large portion of endowments are quasi-endowments rather than true endowments. As noted by Conti-Brown (2011), quasiendowment funds are not subject to the UMIFA restrictions, yet endowments typically do not increase the payout rate from quasi-endowment funds following negative shocks.

\subsection{Interpretation and Discussion}

The results in Tables 3 and 4 are clearly inconsistent with the two normative models of endowment behavior discussed in Section 2. We find that endowments respond asymmetrically

\footnotetext{
${ }^{21}$ Most states relaxed the UMIFA rules over the 2006-2008 period. "At its annual meeting in July 2006, the National Conference of Commissioners on Uniform State Laws approved the Uniform Prudent Management of Institutional Funds Act (UPMIFA) and recommended it for enactment by the legislatures of the various states. UPMIFA is designed to replace the existing Uniform Management of Institutional Funds Act (UMIFA)". See: http://uniformlaws.org/ActSummary.aspx?title=Prudent $\% 20$ Management $\% 20$ of $\% 20$ Institutional $\% 20$ Funds $\% 20$ Act. Under UPMIFA, which has been adopted by 43 states to date, the historical-dollar-value method was replaced with a standard of prudence that applies to the decision-making process of the governing board (Gary 2004; Ehrenberg 2009; and NACUBO-Commonfund 2009). As such, the historical-value constraint would not apply during the later years of our sample and during the 2008-09 financial crisis, allowing endowment payouts even from gifts whose market value is below its historic value.
} 
to shocks and the contemporaneous response to negative shocks is quite substantial. Thus, the Tobin (1974) model, while an elegant description of how some may think endowments ought to behave, does quite poorly in explaining actual endowment payout behavior. The "endowments as self-insurance" hypothesis of Black (1976) and Merton (1992) fairs even worse. Our evidence suggests that endowments' behavior is exactly the opposite of that implied by this theory: rather than increasing payouts following a negative shock, endowments appear to actively reduce their payouts. We further find that the estimated magnitude of this effect is virtually orthogonal to changes in other revenue sources. Moreover, we do not find consistent results across specifications for the revenue shock variables. Thus, we find little to suggest that endowments adjust payouts in response to the overall portfolio of university revenue sources. Finally, while not the focus of this paper, the finding in previous studies that endowment portfolios are heavily concentrated in pro-cyclical asset classes (Lerner, Schoar, and Wang 2008; Gilbert and Hrdlicka 2011) casts further doubt on the self-insurance hypothesis: if universities view endowments as self-insurance, their portfolios would not be so heavily invested in these asset classes.

Our results also rule out two other alternative hypotheses that are not formally modeled in the literature (and thus were not explicitly discussed in Section 2). The first hypothesis is that endowments behave myopically, and respond more quickly to endowment shocks than the smoothing models would imply. This simple model based on myopic behavior would imply a contemporaneous response to both positive and negative shocks, whereas our results indicate that endowments only respond immediately to negative shocks. The second hypothesis is that shorthorizon university officials wish to share endowment "gains" immediately with current faculty and students and postpone the "pain" for future administrators, and pressure endowments to spend accordingly. Such a model would imply a large and immediate response in endowment payouts following positive shocks, and a lagged response to negative shocks. Again, the prediction of this hypothesis is inconsistent with our evidence that endowments reduce payouts immediately in response to negative shocks.

\section{The Endowment Hoarding Hypothesis}

Given the lack of evidence to support the normative models of endowment payout rates, in this section we propose an alternative explanation that is consistent with our findings, namely the endowment hoarding hypothesis, which posits that university and endowment leadership care 
about endowment size above and beyond the endowment's contribution to university operations. For example, if university leaders believe their future employment opportunities and/or prestige are functions of endowment size, they may have an incentive to maintain a large endowment. Moreover, the compensation of university leaders tends to rise with the growth of endowment size. For example, Ehrenberg (2009) reports that university presidents are compensated at least in part based on endowment size. These incentives could cause university presidents to respond slowly to positive shocks in order to grow the endowment, but quickly cut endowment payouts following negative shocks in order to maintain endowment size. Our results are consistent with this prediction of the endowment hoarding hypothesis: following positive shocks, endowments are slow to increase payouts, thus allowing the endowment to grow. In contrast, following negative shocks, endowments are quick to reduce payouts below the level implied by their own payout rules, thus limiting the "hit" to the size of the endowment.

To test this idea further, it is useful to look for evidence in situations where incentives for endowment hoarding are likely to be strongest. To do this, we draw upon the corporate finance literature; Baker and Xuan (2009) find evidence that the stock price at the time the CEO joined the firm serves as a reference point when deciding whether to conduct a seasoned equity offering or to repurchase shares. In a similar spirit, we hypothesize that university presidents might use the size of the endowment at the time they became president as an important benchmark when deciding upon endowment payouts. Our hypothesis is that endowment payouts are more likely to be reduced following a negative shock if the current endowment value is close to the president's benchmark (i.e., the value when he or she became president).

To test this hypothesis, we construct a variable, president's benchmark ratio, defined as the ratio of the endowment's value at the start of the current year to the endowment's value when the university president took office. We also construct an indicator variable for whether this ratio lies between 0.9 and 1.1 (12\% of our observations). We hypothesize that when endowment values are either just above or just below this personal benchmark, university presidents are especially sensitive to maintaining the size of the endowment. In Table 5, we show how these variables are related to endowment payout rates. In columns (1) and (2), respectively, we show that the log of the president's benchmark ratio is positively correlated with payout rates, but that this effect disappears once we control for university fixed effects. In columns (3), (4), and (5), we show that being close to the benchmark value is negatively correlated with payout rates, and 
that the magnitude of this effect is robust to controlling for the log ratio as well as for university fixed effects. We find that payout rates are approximately 25 basis points lower for those endowments that are close to the president's benchmark. ${ }^{22}$

In Table 6, we repeat the three regressions from Table 3, but also include an interaction between the shock variables and an indicator variable for endowment-year observations that are within $10 \%$ of the president's benchmark. Recall that our key finding from Table 3 was that universities respond to negative endowment shocks by reducing payouts. Here, we find that this result is driven entirely by those universities whose current endowment value is close (within $10 \%$ ) to the value of the endowment when the president started. Thus, for universities that are close to the current president's benchmark, a negative endowment shock equal to $10 \%$ of the university's budget leads to a 46 basis point reduction in the endowment's payout rate $(0.10 *(0.82+3.73)=0.46)-$ see column $(3)$ of Table 6 . For universities whose endowment value is farther away from the president's benchmark, there is no significant relation between financial shocks and endowment payout rates.

In Table 7, we continue to focus on the effect of endowment shocks on payout rates for universities whose endowment size is near to the president's benchmark. The coefficient estimates reported in Table 7 are the sum of each shock variable and its interaction with "Near Benchmark" (i.e., indicator variable that takes the value of one if the value of the university endowment at the start of the year is $90-110 \%$ of the value of the endowment when the current university president took office and zero otherwise) - this sum represents the effect of an endowment shock on payout rates for an endowment near the benchmark.

The first three columns of Table 7 replicate the results in Table 6. Columns (4)-(6) report results when the shock variables are also interacted with the log of the president's benchmark ratio. Columns (7)-(9) report results when the shock variables are also interacted with the tenure (in years) of the current university president. In all regressions, we find that the importance of "Near Benchmark" in explaining the asymmetry in payout behavior remains unchanged. We also find that the coefficient estimates on the interaction terms in columns (4)-(9) are insignificant. The results in columns (4)-(6) show that the results in Table 6 are not driven by a

\footnotetext{
${ }^{22}$ We have fewer observations in these payout regressions for several reasons. First, we do not use observations from the president's first year on the job. Second, data on university presidents first became available in IPEDS in 1990. Thus we are unable to calculate the president's benchmark for presidents who began their tenure before 1990, and these observations are excluded.
} 
general linear relation between endowment shocks and the president's benchmark, but rather the results are specific to endowments whose current size is in a narrow band around their historic size when the president took office. The results in columns (7)-(9) make clear that our results concerning payout policy when the value of the university endowment is "near a benchmark" do not simply pick up a spurious correlation between a president's tenure and payout decisions. ${ }^{23}$

\section{Do Shocks Matter? The Effect of Endowment Shocks on University Personnel}

Our empirical results thus far indicate that universities with larger negative endowment shocks respond by reducing their payout rates relative to universities with smaller shocks. As a result, universities experiencing a negative endowment shock, one important component of their revenue streams, must respond along some other margin. We show in our regressions above that this adjustment does not occur via other revenue sources. Thus, to further understand how universities that experience large negative endowment shocks behave, we investigate how these shocks affect the most important university expenditure - personnel.

In Table 8, we show the effect of endowment shocks on university employment decisions. The dependent variable in the regressions is the logarithm of the number of employees in a specific job category (i.e., tenure-system faculty, adjuncts/lecturers, support staff, maintenance, and administrators). As with the payout regressions, we report the coefficient estimates on the contemporaneous and lagged measures of the positive and negative endowment shock. For each job category, we report regression results without and with the additional revenue shock variables (in the odd and even numbered columns, respectively).

The results in columns (1) and (2) suggest that universities respond to a negative shock by reducing the number of tenure-system faculty (especially with a one-year lag). As in the payout regressions, by "reduce" we mean a reduction relative to otherwise similar universities, which could imply either a reduction in absolute terms or a smaller increase. In column (2), for an endowment shock equal to losing $10 \%$ of a university's budget, we observe a contemporaneous $2.9 \%$ reduction in tenure-system faculty, with an additional $6.1 \%$ reduction in the subsequent year. This reduction in tenure-system faculty could be accomplished through a reduction in new hires, an increased attrition rate (i.e., failing to replace faculty who retire or

\footnotetext{
${ }^{23}$ In unreported results, we re-estimate these regressions, but exclude all universities at which the president's tenure is less than three years. The results are similar.
} 
depart), or increased terminations (at least for non-tenured faculty). Although the corresponding coefficient estimates for the negative shocks are of similar magnitude for adjuncts (reported in columns (3) and (4)), they are imprecisely measured and are thus not statistically significant.

The next four columns (columns (5)-(8)) indicate that following a negative endowment shock, universities also make very significant and immediate cuts in the number of support employees (e.g., secretaries) and maintenance workers. A negative endowment shock equivalent to a $10 \%$ reduction in a university's budget results in a $6.5 \%$ decline in the number of support employees and a $4.3 \%$ reduction in maintenance employees in the year of the shock. In contrast, according to columns (9) and (10) in Table 8 , university administrators ${ }^{24}$ are unaffected - there is no significant response to contemporaneous or lagged shocks for this group. ${ }^{25}$

As discussed earlier, the relative curtailing of endowment payouts in response to negative shocks is largely concentrated among universities at which the current endowment size is near to the historical endowment size when the president joined. One would expect the operational responses documented in Table 8, to also be more substantial at these universities. This is exactly what we find in Table 9 where we interact the four endowment shock variables with an indicator variable equal to one if the endowment is "Near Benchmark". For tenure-system faculty, support staff, and maintenance employees, the university's contemporaneous response to a negative shock to the endowment is at least twice as large if the endowment is near the president's benchmark than if it is not. In column (1), for every $10 \%$ of a university's budget that is lost in an endowment shock, we observe a contemporaneous $7.6 \%$ reduction in tenuresystem faculty if the endowment is near the benchmark but only a $3.4 \%$ reduction if it is not.

\footnotetext{
${ }^{24}$ For reporting purposes, IPEDS assigns personnel into a single job category (e.g., tenure-system faculty or administration) based on the role in which they spend more than half of their time. Although we recognize that the classification of personnel into faculty versus administrators may vary across universities, the inclusion of university fixed effects will control for these differences provided the classifications are reasonably consistent within universities over time. There is no reason to believe that our finding is driven by a labeling issue, unless universities are more likely to re-classify faculty as administrators following negative shocks, and then revert back to labeling them as faculty in years without negative shocks.

${ }^{25}$ Summing the coefficient estimates on the contemporaneous and lagged negative shock variables results in the cumulative two-year university response. For tenure-system faculty, the sum of coefficient estimates is 0.90 , which is significant at the $1 \%$ level. This point estimate suggests that tenure-system faculty face a relative reduction in numbers on the order of $9 \%$ during the two years following a negative endowment shock that represents a $10 \%$ loss to the university budget (relative to a university with no endowment shock). The sum of the coefficient estimates for administrators is -0.44 , suggesting that their ranks actually increase by $5 \%$ following the negative shock (though this estimate is not statistically different from zero). However, the two-year cumulative effect on hiring following a negative endowment shock for administrators is significantly different from that for tenure-system faculty at the 5\% level. Thus, the number of administrators employed is significantly less likely to decrease (or more likely to increase) in the event of a negative endowment shock, when compared with tenure-system faculty.
} 
Such a shock also results in a contemporaneous $7.0 \%$ decline in the number of secretaries if the endowment is near the president's benchmark (the cutbacks are about half this size if the endowment is not near the benchmark).

\section{Conclusions}

Over the past few decades, the growth rate of university endowments has far outpaced that of university expenditures, and endowment payouts have become an increasingly important component of most universities' revenues. We use financial shocks to endowments, particularly the responses to the technology-bubble collapse in 2001-2002 and the financial crisis in 20082009 , to study both the payout decisions of endowment funds and the resultant effects on universities' operational decisions.

We find that the payout policies of university endowments are generally inconsistent with the endowment models of Tobin (1974), Black (1976), and Merton (1992), in which endowment funds seek to smooth payouts or self-insure against shocks to aggregate university revenues. Instead, we find that although most universities have formal policies intended to smooth payouts over time, endowments significantly deviate from these policies following negative financial shocks by reducing payouts by more than their formal smoothing policies would suggest.

Our results are consistent with a model in which university leaders care directly about the size of the endowment, perhaps due to the private benefits (e.g., prestige, future career opportunities, high compensation, etc.) they obtain from a larger endowment. Consistent with this view, we find that our key results are driven primarily by endowments whose current value is close to the historical value when the current president's tenure began.

Next, we find that financial shocks to an endowment have real consequences for the operational decisions of the university. As a result of negative endowment shocks, universities cut back on the hiring (or accelerate the firing) of employees across all job categories, with the exception of university administrators. Consistent with our results on payout reductions, we find that these effects are driven primarily by endowments that are close to their benchmark value.

Taken as a whole, our results provide strong evidence that endowment shocks have an important and significant effect on payout policies and the real operations of the universities that these endowments support. Thus, our results provide new evidence on an unexplored channel through which financial markets affect real investments. 


\section{References}

Baker, Malcolm, and Yuhai Xuan, "Under New Management: Equity Issues and Attribution of Past Returns," Working Paper, Harvard Business School (2009).

Barber, Brad M., and Guojun Wang, “Do (Some) University Endowments earn Alpha?,” Working Paper, University of California - Davis (2011).

Black, Fisher, "The Investment Policy Spectrum: Individuals, Endowment Funds and Pension Funds," Financial Analysts Journal 32 (1976), 23-31.

Bowen, William G., and David W. Breneman, "Price Discount or Educational Investment?," Brookings Review 11 (1993), 28-23.

Brown, Jeffrey R., Stephen G. Dimmock, Jun-Koo Kang, David Richardson, and Scott Weisbenner, "The Governance of University Endowments: Insights from a TIAA-CREF Institute Survey," TIAA-CREF Institute Research Dialogue 102 (2011).

Brown, Keith C., Lorenzo Garlappi, and Cristian Tiu, "Asset Allocation and Portfolio Performance: Evidence from University Endowment Funds," Journal of Financial Markets 13 (2010), $268-294$.

Clotfelter, Charles T., "The Familiar but Curious Economics of Higher Education: Introduction to a Symposium," Journal of Economic Perspectives 13 (1999), 3-12.

Conti-Brown, Peter, "Scarcity Amidst Wealth: The Law, Finance, and Culture of Elite University Endowments in Financial Crisis," Stanford Law Review 63 (2011), 699-749.

Dimmock, Stephen G., "Background Risk and University Endowment Funds," Review of Economics and Statistics 94 (2012), 789-799.

Ehrenberg, Ronald G., "Demystifying Endowments," TIAA-CREF Institute Research Paper (2009).

Eisner, Robert, "Endowment Income, Capital Gains and Inflation Accounting - Discussion," American Economic Review 64 (1974), 438-442.

Gary, Susan, "Revisions to the Uniform Management of Institutional Funds Act," ACTEC Journal 189 (2004), 189-192.

Gilbert, Thomas, and Christopher Hrdlicka, "Why Do University Endowments Invest So Much In Risky Assets? A Model of Equity-Less Producers," Working Paper, University of Washington (2011).

Hansmann, Henry, "Why Do Universities Have Endowments?," Journal of Legal Studies 19 (1990), 3-42. 
James, Estelle, "Decision Process and Priorities in Higher Education," In The Economics of American Universities, Stephan Hoenack and Eileen Collins, editors (Buffalo, NY: State University of New York Press, 1990).

Lerner, Josh, Antoinette Schoar, and Jialan Wang, "Secrets of the Academy: The Drivers of University Endowment Success," Journal of Economic Perspectives 22 (2008), 207-222.

Litvack, James M., Burton G. Malkiel, and Richard E. Quandt, "A Plan for the Definition of Endowment Income,” American Economic Review 64 (1974), 433-442.

Merton, Robert C., "Optimal Investment Strategies for University Endowment Funds," In Continuous Time Finance - Revised Edition, Robert C. Merton, editor (Malden, MA: Blackwell Publishers, 1992).

Modigliani, Franco, and Merton Miller, "The Cost of Capital, Corporation Finance and the Theory of Investment," American Economic Review 48 (1958), 261-297.

NACUBO-Commonfund, "NACUBO-Commonfund Study of Endowments,” (2009).

Nichols, Donald A., "The Investment Income Formula of the American Economic Association," American Economic Review 64 (1974), 420-426.

Sedlacek, Verne O., and William F. Jarvis, "Endowment Spending: Building a Stronger Policy Framework," Commonfund White Paper (2010).

Swensen, David F., Pioneering Portfolio Management: An Unconventional Approach to Institutional Investment, (New York, NY: Free Press, 2000).

Tobin, James, "What is Permanent Endowment Income?," American Economic Review 64 (1974), 427-432.

Winston, Gordon C., "Subsidies, Hierarchy and Peers: The Awkward Economics of Higher Education," Journal of Economic Perspectives 13 (1999), 13-36. 
Figure 1: Aggregate Market Value of Endowment Fund Assets at Doctoral Universities, 1986-2009

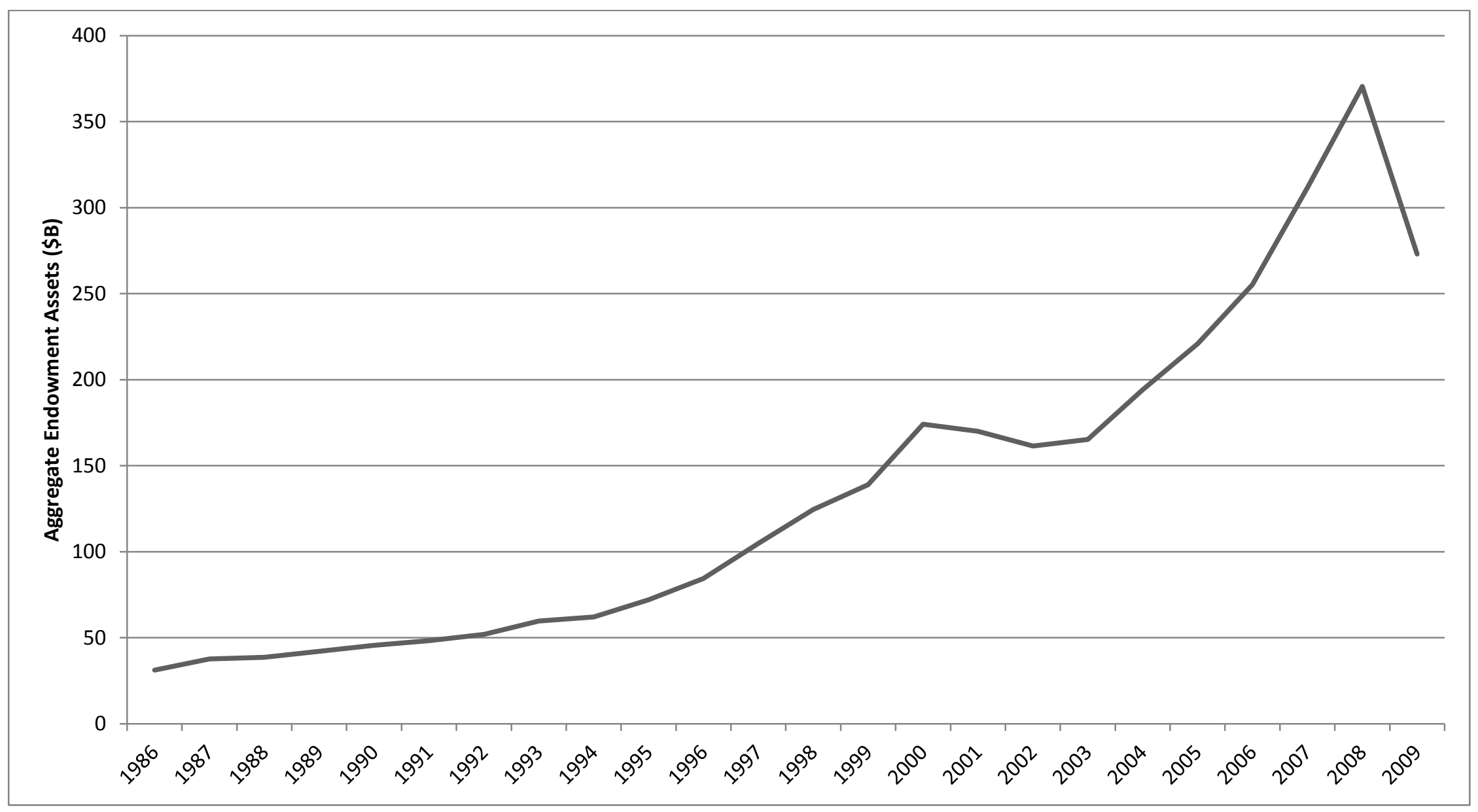

Source: NACUBO. Year refers to academic year (e.g., 2009 is the 2008-09 academic year). Endowment values are measured at the end of the academic year. 
Figure 2: Growth Rate of Endowment Size (Market Value) and University Costs at Doctoral Universities, 1986-2009

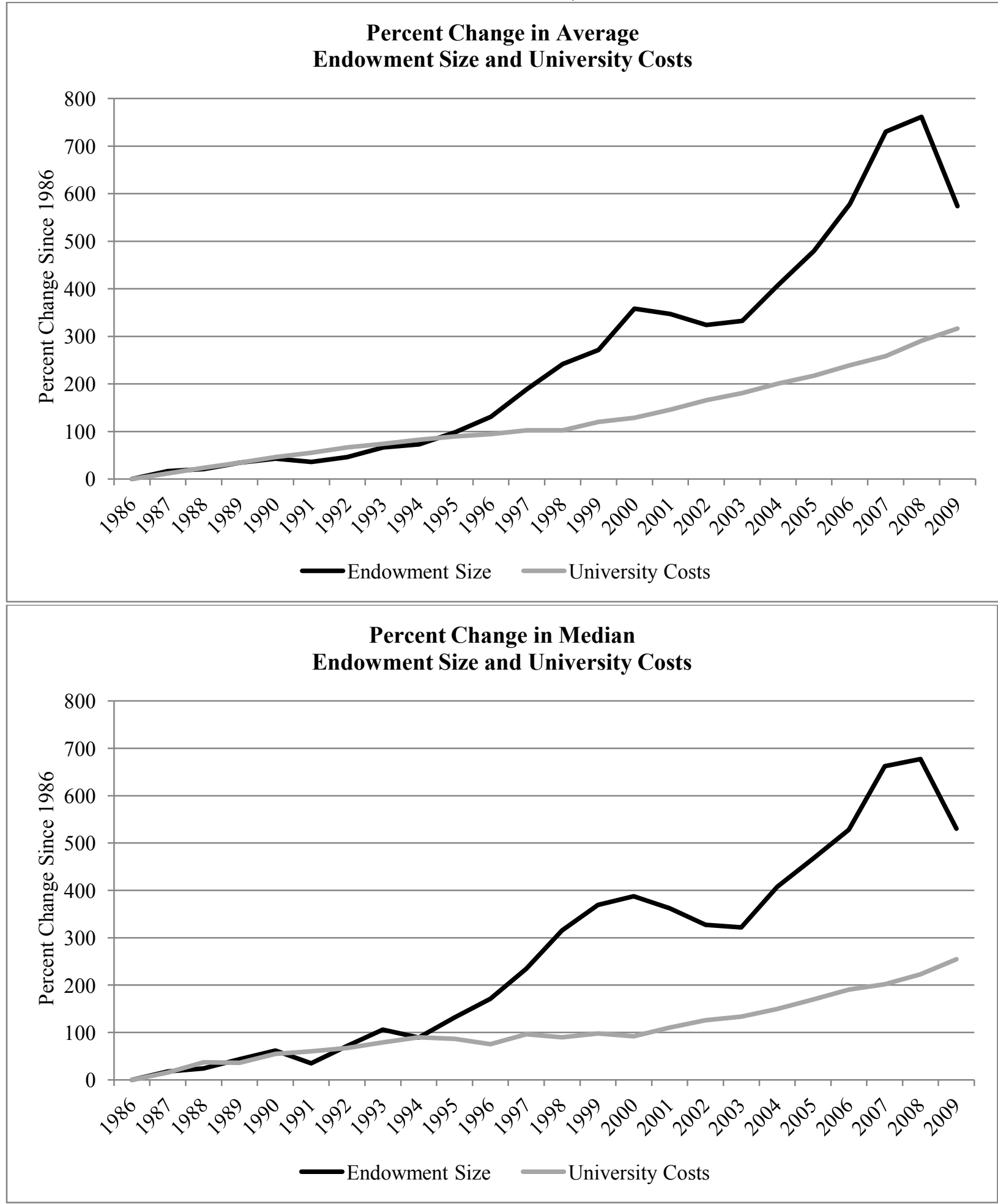

Source: NACUBO for endowment market values and IPEDS for total university costs. Year refers to academic year (e.g., 2009 is the 2008-09 academic year). Endowment values are measured at the end of the academic year and university costs are measured during the year. 
Figure 3: Distribution of Endowment Returns at Doctoral Universities, 1986-2009

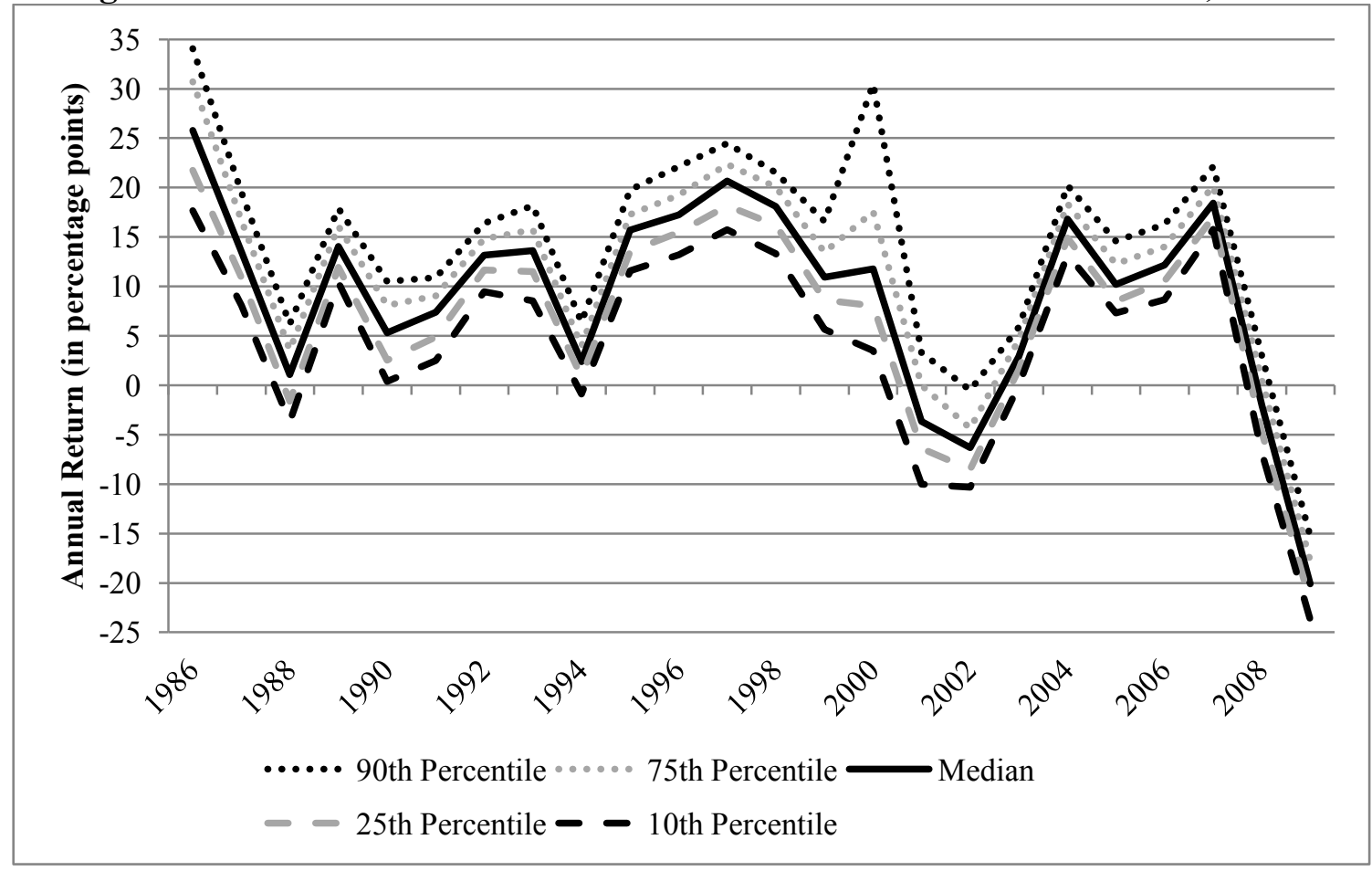

Source: NACUBO. Year refers to academic year (e.g., 2009 is the 2008-09 academic year).

Figure 4: Distribution of Endowment Shocks at Doctoral Universities, 1986-2009

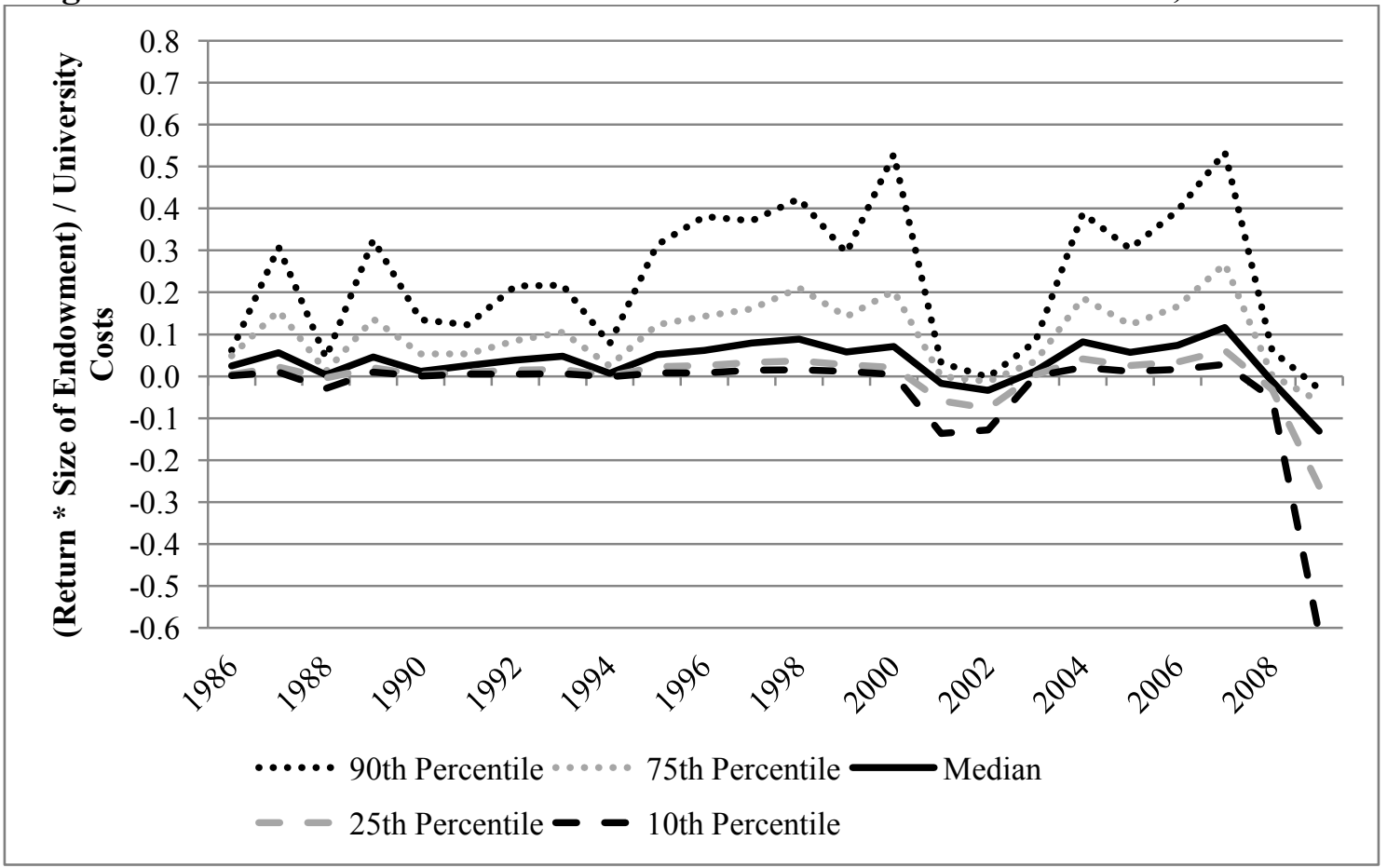

Source: NACUBO for endowment returns and market value and IPEDS for university costs. Year refers to academic year (e.g., 2009 is the 2008-09 academic year). The endowment shock for a university for a given year is defined as the endowment return during the year multiplied by the endowment market value at the end of the prior year normalized by total university costs during the prior year. 
Table 1: Distributions of Various Characteristics of Endowments and Operations of Doctoral Universities, 1986-2009

\begin{tabular}{|c|c|c|c|c|c|c|c|}
\hline & Mean & Std. Dev. & 10th & 25th & Median & 75th & 90th \\
\hline \multicolumn{8}{|l|}{ Endowment Size, Payouts, and Performance } \\
\hline Assets (market value, $\$ \mathrm{M}$ ) & 738.9 & $2,091.7$ & 30.8 & 66.7 & 193.4 & 575.8 & $1,537.3$ \\
\hline Endowment-to-University-Cost Ratio & 1.03 & 1.65 & 0.10 & 0.22 & 0.51 & 1.13 & 2.29 \\
\hline Dollar Payout (\$M) & 40.5 & 105.4 & 2.0 & 4.4 & 11.1 & 34.0 & 90.6 \\
\hline Contemporaneous Payout Rate (in percent) & 5.2 & 1.3 & 3.8 & 4.5 & 5.2 & 5.9 & 6.7 \\
\hline Payout-to-University-Cost Ratio & 0.052 & 0.080 & 0.006 & 0.012 & 0.025 & 0.056 & 0.123 \\
\hline Return (in percent) & 9.0 & 11.4 & -5.9 & 2.0 & 11.0 & 16.8 & 20.9 \\
\hline Endowment Shock & 0.09 & 0.26 & -0.03 & 0.00 & 0.03 & 0.10 & 0.26 \\
\hline \multicolumn{8}{|l|}{ Non-Endowment Revenue Sources } \\
\hline Government Appropriations (share of all revenue) & 0.21 & 0.19 & 0.00 & 0.00 & 0.22 & 0.38 & 0.47 \\
\hline Net Tuition Revenue (share of all revenue) & 0.31 & 0.20 & 0.11 & 0.16 & 0.25 & 0.40 & 0.64 \\
\hline Government Gifts, Grants, and Contracts (share of all revenue) & 0.19 & 0.18 & 0.06 & 0.10 & 0.14 & 0.21 & 0.31 \\
\hline Revenue Shock (from government revenue sources) & 0.01 & 0.09 & -0.02 & 0.001 & 0.02 & 0.04 & 0.06 \\
\hline \multicolumn{8}{|l|}{ Budget, Employment, and Salary Data } \\
\hline Total University Costs (\$M) & 620 & 660 & 113 & 201 & 386 & 773 & 1,450 \\
\hline Total Salary and Benefits for All Employees (\$M) & 361 & 434 & 65 & 118 & 221 & 419 & 825 \\
\hline Budget Share of Salary and Benefits for All Employees & 0.58 & 0.21 & 0.42 & 0.51 & 0.57 & 0.61 & 0.65 \\
\hline Total Number of Employees & 4,892 & 3,671 & 1,294 & 2,102 & 3,897 & 6,841 & 10,064 \\
\hline \multicolumn{8}{|l|}{ Employee Share of Total University Employment } \\
\hline Share of Tenure-System Faculty & 0.26 & 0.11 & 0.14 & 0.18 & 0.23 & 0.31 & 0.41 \\
\hline Share of Adjuncts & 0.07 & 0.05 & 0.02 & 0.03 & 0.06 & 0.09 & 0.14 \\
\hline Share of Support Employees & 0.48 & 0.11 & 0.33 & 0.41 & 0.48 & 0.55 & 0.61 \\
\hline Share of Maintenance Employees & 0.12 & 0.05 & 0.06 & 0.10 & 0.12 & 0.15 & 0.18 \\
\hline Share of Administrators & 0.08 & 0.05 & 0.03 & 0.04 & 0.06 & 0.10 & 0.14 \\
\hline
\end{tabular}

Source: IPEDS. Year represents academic year (e.g., 2009 represents the 2008-09 academic year). 
Table 2: Relation between Payouts from Endowments and Endowment Returns

\begin{tabular}{|c|c|c|c|c|}
\hline & \multicolumn{4}{|c|}{ Ln(Endowment Payouts in \$), 1993-2009 } \\
\hline & (1) & (2) & (3) & (4) \\
\hline $\operatorname{Return}_{i, t}$ & $\begin{array}{l}0.27^{* *} \\
(0.12)\end{array}$ & & $\begin{array}{l}0.48^{* * *} \\
(0.16)\end{array}$ & \\
\hline $\operatorname{Return}_{i, t}^{+}=\operatorname{Max}\left(\operatorname{Return}_{i, t}, 0\right)$ & & $\begin{array}{r}0.14 \\
(0.14)\end{array}$ & & $\begin{array}{r}0.32^{*} \\
(0.19)\end{array}$ \\
\hline $\operatorname{Return}_{i, t}^{-}=\operatorname{Min}\left(\operatorname{Return}_{i, t}, 0\right)$ & & $\begin{array}{l}0.81^{* * *} \\
(0.31)\end{array}$ & & $\begin{array}{l}1.08^{* * *} \\
(0.38)\end{array}$ \\
\hline $\begin{array}{l}p \text {-value of test } \\
\operatorname{Return}_{i, t}^{+}=\operatorname{Return}_{i, t}^{-}\end{array}$ & N/A & $0.062^{*}$ & N/A & $0.086^{*}$ \\
\hline $\begin{array}{l}\text { University Fixed Effects } \\
\text { Year Fixed Effects } \\
\text { State-by-Year-by-Private Fixed Effects } \\
\text { R-squared (within a university) } \\
\text { Number of Observations }\end{array}$ & $\begin{array}{r}\text { Yes } \\
\text { Yes } \\
\text { No } \\
0.72 \\
3,000\end{array}$ & $\begin{array}{r}\text { Yes } \\
\text { Yes } \\
\text { No } \\
0.72 \\
3,000\end{array}$ & $\begin{array}{r}\text { Yes } \\
\text { Subsumed } \\
\text { Yes } \\
0.85 \\
3,000 \\
\end{array}$ & $\begin{array}{r}\text { Yes } \\
\text { Subsumed } \\
\text { Yes } \\
0.85 \\
3,000 \\
\end{array}$ \\
\hline
\end{tabular}

See the Appendix for variable definitions. Standard errors, shown in parentheses, allow for correlations among observations of a given university over time as well as cross-sectional correlations. ${ }^{* * *},{ }^{* *},{ }^{*}$ denote significance at the $1 \%, 5 \%$, and $10 \%$ levels, respectively. 
Table 3: Payout Rates of University Endowments (in percentage points)

\begin{tabular}{|c|c|c|c|}
\hline & \multicolumn{3}{|c|}{ Payout Rate, 1993-2009 } \\
\hline & (1) & (2) & (3) \\
\hline $\operatorname{Shock}_{i, t}^{+}=\operatorname{Max}\left(\operatorname{Shock}_{i, t}, 0\right)$ & $\begin{array}{r}-0.02 \\
(0.17)\end{array}$ & $\begin{array}{r}0.09 \\
(0.18)\end{array}$ & $\begin{array}{r}0.11 \\
(0.19)\end{array}$ \\
\hline $\operatorname{Shock}_{i, t}^{-}=\operatorname{Min}_{\left(\operatorname{Shock}_{i, t}, 0\right)}$ & $\begin{array}{l}1.83^{* *} \\
(0.78)\end{array}$ & $\begin{array}{l}1.68^{* *} \\
(0.80)\end{array}$ & $\begin{array}{l}1.93^{* *} \\
(0.83)\end{array}$ \\
\hline Shock $_{i, t-1}^{+}$ & & $\begin{array}{l}-0.50^{* * *} \\
(0.18)\end{array}$ & $\begin{array}{l}-0.48^{* *} \\
(0.19)\end{array}$ \\
\hline Shock $_{i, t-1}^{-}$ & & $\begin{array}{r}-0.24 \\
(0.99)\end{array}$ & $\begin{array}{r}-0.31 \\
(1.00)\end{array}$ \\
\hline $\operatorname{Rev}_{\text {Shock }}^{+}, t$ & & & $\begin{array}{r}0.51 \\
(0.80)\end{array}$ \\
\hline $\operatorname{Rev}_{S^{\prime}} \operatorname{cock}_{i, t}^{-}$ & & & $\begin{array}{r}-0.71 \\
(1.05)\end{array}$ \\
\hline $\operatorname{Rev}_{S^{\prime}} \operatorname{coc}_{i, t-1}^{+}$ & & & $\begin{array}{r}0.14 \\
(0.71)\end{array}$ \\
\hline $\operatorname{Rev}_{S^{\prime}} \operatorname{cock}_{i, t-1}^{-}$ & & & $\begin{array}{l}-1.93^{*} \\
(1.15)\end{array}$ \\
\hline Joint $p$-value of Endowment Shocks & N/A & $\mathrm{N} / \mathrm{A}$ & $0.005^{* * *}$ \\
\hline$p$-value of test $\operatorname{Shock}_{i, t}^{+}=\operatorname{Shock}_{i, t}^{-}$ & $0.028^{* *}$ & $0.067^{*}$ & $0.043^{* *}$ \\
\hline$p$-value of test $\operatorname{Shock}_{i, t-1}^{+}=\operatorname{Shock}_{i, t-1}^{-}$ & N/A & 0.803 & 0.872 \\
\hline Joint $p$-value of Revenue Shocks & N/A & N/A & 0.490 \\
\hline$p$-value of $\operatorname{Rev} \operatorname{Shock}_{i, t}^{+}=\operatorname{Rev} \operatorname{Shock}_{i, t}^{-}$ & N/A & $\mathrm{N} / \mathrm{A}$ & 0.396 \\
\hline$p$-value of Rev $\operatorname{Shock}_{i, t-1}^{+}=\operatorname{Rev}^{-} \operatorname{Shock}_{i, t-1}^{-}$ & N/A & N/A & 0.153 \\
\hline University Fixed Effects & Yes & Yes & Yes \\
\hline State-by-Year-by-Private Fixed Effects & Yes & Yes & Yes \\
\hline R-squared (within a university) & 0.54 & 0.55 & 0.54 \\
\hline Number of Observations & 2,958 & 2,893 & 2,869 \\
\hline
\end{tabular}

See the Appendix for variable definitions. Standard errors, shown in parentheses, allow for correlations among observations of a given university over time as well as cross-sectional correlations. ${ }^{* * *},{ }^{* *},{ }^{*}$ denote significance at the $1 \%, 5 \%$, and $10 \%$ levels, respectively. 
Table 4: Deviations from Endowment Payout Policy and UMIFA Constraints (in percentage points)

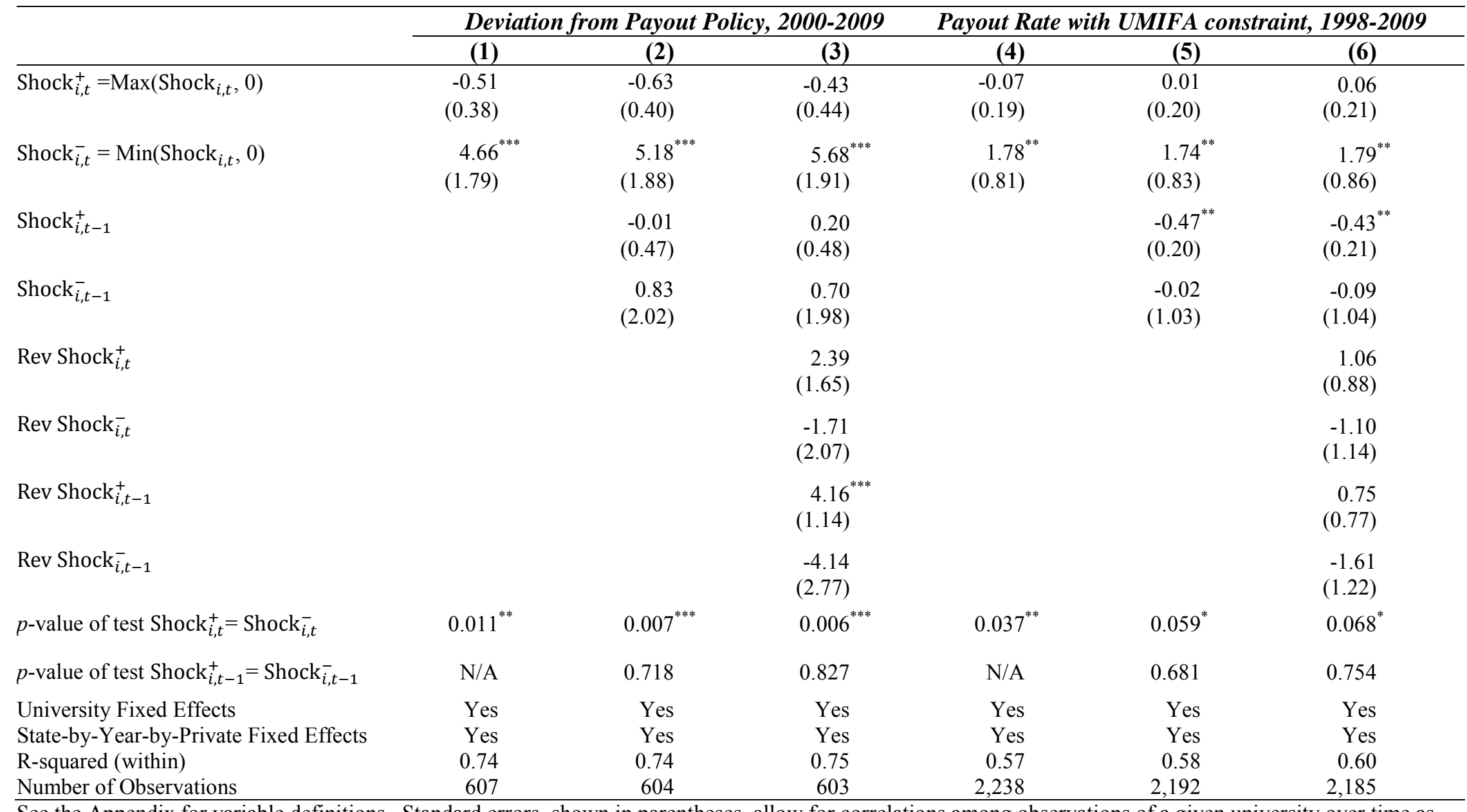

See the Appendix for variable definitions. Standard errors, shown in parentheses, allow for correlations among observations of a given university over time as well as cross-sectional correlations. ${ }^{* * *},{ }^{* *},{ }^{*}$ denote significance at the $1 \%, 5 \%$, and $10 \%$ levels, respectively. 
Table 5: Relation Between Endowment Payout Rates and the University President's Benchmark

\begin{tabular}{|c|c|c|c|c|c|}
\hline & \multicolumn{5}{|c|}{ Payout Rate (in percent) } \\
\hline & (1) & (2) & (3) & (4) & (5) \\
\hline Ln(Ratio of Endowment Value at Start of Year to Endowment Value when & $0.19^{* *}$ & 0.07 & & & 0.02 \\
\hline Current University President Took Office) & $(0.09)$ & $(0.13)$ & & & $(0.13)$ \\
\hline Near Benchmark & & & $\begin{array}{l}-0.26^{* *} \\
(0.13)\end{array}$ & $\begin{array}{l}-0.24^{* *} \\
(0.11)\end{array}$ & $\begin{array}{l}-0.24^{* *} \\
(0.11)\end{array}$ \\
\hline University Fixed Effects & No & Yes & No & Yes & Yes \\
\hline Number of Observations & 2,004 & 2,004 & 2,004 & 2,004 & 2,004 \\
\hline
\end{tabular}

See the Appendix for variable definitions. "Near Benchmark" is an indicator for whether the value of the university endowment at the start of the year is $90-110 \%$ of the value of the endowment when the current university president took office. Standard errors, shown in parentheses, allow for correlations among observations of a given university over time as well as cross-sectional correlations. ${ }^{* * *},{ }^{* *},{ }^{*}$ denote significance at the $1 \%, 5 \%$, and $10 \%$ levels, respectively. 


\begin{tabular}{|c|c|c|c|}
\hline & \multicolumn{3}{|c|}{ Payout Rate (in percent) } \\
\hline & $(1)$ & (2) & (3) \\
\hline Shock $_{i, t}^{+}$ & $\begin{array}{r}-0.43 \\
(0.28)\end{array}$ & $\begin{array}{r}-0.19 \\
(0.31)\end{array}$ & $\begin{array}{c}-0.11 \\
(0.32)\end{array}$ \\
\hline Shock $_{i, t}^{+} *$ Near Benchmark & $\begin{array}{r}0.22 \\
(0.43)\end{array}$ & $\begin{array}{c}-0.38 \\
(0.63)\end{array}$ & $\begin{array}{r}-0.39 \\
(0.63)\end{array}$ \\
\hline $\operatorname{Shock}_{i, t}^{-}$ & $\begin{array}{r}0.86 \\
(1.13)\end{array}$ & $\begin{array}{r}0.72 \\
(1.17)\end{array}$ & $\begin{array}{r}0.82 \\
(1.23)\end{array}$ \\
\hline Shock $_{i, t}^{-} *$ Near Benchmark & $\begin{array}{c}2.73^{* *} \\
(1.35)\end{array}$ & $\begin{array}{c}3.54^{* *} \\
(1.58)\end{array}$ & $\begin{array}{c}3.73^{* *} \\
(1.60)\end{array}$ \\
\hline $\operatorname{Shock}_{i, t-1}^{+}$ & & $\begin{array}{c}-0.44 \\
(0.31)\end{array}$ & $\begin{array}{r}-0.42 \\
(0.32)\end{array}$ \\
\hline $\operatorname{Shock}_{i, t-1}^{+} *$ Near Benchmark & & $\begin{array}{r}0.47 \\
(0.55)\end{array}$ & $\begin{array}{r}0.51 \\
(0.55)\end{array}$ \\
\hline Shock $_{i, t-1}^{-}$ & & $\begin{array}{r}-1.00 \\
(1.54)\end{array}$ & $\begin{array}{r}-1.23 \\
(1.56)\end{array}$ \\
\hline Shock $_{i, t-1}^{-} *$ Near Benchmark & & $\begin{array}{r}-1.77 \\
(2.71)\end{array}$ & $\begin{array}{r}-1.83 \\
(2.72)\end{array}$ \\
\hline Revenue Shock Controls & No & No & Yes \\
\hline University Fixed Effects & Yes & Yes & Yes \\
\hline State-by-Year-by-Private Fixed Effects & Yes & Yes & Yes \\
\hline R-squared (within) & 0.57 & 0.58 & 0.57 \\
\hline Number of Observations & 2,004 & 2,004 & 1,991 \\
\hline
\end{tabular}

See the Appendix for variable definitions. Each shock variables is interacted with an indicator for whether the value of the university endowment at the start of the year is $90-110 \%$ of the value of the endowment when the current university president took office ("Near Benchmark"). Standard errors, shown in parentheses, allow for correlations among observations of a given university over time as well as cross-sectional correlations. ${ }^{* * *},{ }^{* *},{ }^{*}$ denote significance at the $1 \%, 5 \%$, and $10 \%$ levels, respectively. 
Table 7: Effect of Endowment Shocks on Payout Rates for Universities with Endowment Size Near President's Benchmark

\begin{tabular}{|c|c|c|c|c|c|c|c|c|c|}
\hline & \multicolumn{9}{|c|}{ Payout Rate (in percent) } \\
\hline & (1) & (2) & (3) & (4) & (5) & (6) & (7) & (8) & (9) \\
\hline $\begin{array}{l}\left(\operatorname{Shock}_{i, t}^{+}\right)+\left(\operatorname{Shock}_{i, t}^{+} * \text { Near Benchmark }\right) \\
(\text { total effect for endowment near benchmark) }\end{array}$ & $\begin{array}{r}-0.21 \\
(0.49)\end{array}$ & $\begin{array}{l}-0.56 \\
(0.61)\end{array}$ & $\begin{array}{r}-0.50 \\
(0.62)\end{array}$ & $\begin{array}{r}-0.33 \\
(0.50)\end{array}$ & $\begin{array}{l}-0.66 \\
(0.62)\end{array}$ & $\begin{array}{r}-0.59 \\
(0.62)\end{array}$ & $\begin{array}{r}-0.27 \\
(0.51)\end{array}$ & $\begin{array}{r}-0.47 \\
(0.63)\end{array}$ & $\begin{array}{r}-0.369 \\
(0.64)\end{array}$ \\
\hline $\begin{array}{l}\left(\operatorname{Shock}_{i, t}^{-}\right)+\left(\operatorname{Shock}_{i, t}^{-} * \text { Near Benchmark }\right) \\
(\text { total effect for endowment near benchmark) }\end{array}$ & $\begin{array}{l}3.60^{* *} \\
(1.67)\end{array}$ & $\begin{array}{l}4.26^{* *} \\
(1.78)\end{array}$ & $\begin{aligned} & 4.55^{* *} \\
&(1.88)\end{aligned}$ & $\begin{array}{l}3.71^{* *} \\
(1.69)\end{array}$ & $\begin{array}{l}4.33^{* *} \\
(1.81)\end{array}$ & $\begin{array}{l}4.68^{* *} \\
(1.90)\end{array}$ & $\begin{array}{l}3.59^{* *} \\
(1.78)\end{array}$ & $\begin{array}{l}3.94^{* *} \\
(1.91)\end{array}$ & $\begin{array}{l}4.16^{* *} \\
(1.96)\end{array}$ \\
\hline $\begin{array}{l}\left(\operatorname{Shock}_{i, t-1}^{+}\right)+\left(\text {Shock }_{i, t-1}^{+} * \text { Near Benchmark }\right) \\
(\text { total effect for endowment near benchmark) }\end{array}$ & & $\begin{array}{r}0.03 \\
(0.54)\end{array}$ & $\begin{array}{r}0.09 \\
(0.54)\end{array}$ & & $\begin{array}{r}-0.03 \\
(0.54)\end{array}$ & $\begin{array}{r}0.02 \\
(0.54)\end{array}$ & & $\begin{array}{r}-0.09 \\
(0.55)\end{array}$ & $\begin{array}{r}-0.04 \\
(0.55)\end{array}$ \\
\hline $\begin{array}{l}\left(\operatorname{Shock}_{i, t-1}^{-}\right)+\left(\text {Shock }_{i, t-1}^{-} * \text { Near Benchmark }\right) \\
(\text { total effect for endowment near benchmark) }\end{array}$ & & $\begin{array}{r}-2.77 \\
(2.48)\end{array}$ & $\begin{array}{l}-3.06 \\
(2.50)\end{array}$ & & $\begin{array}{r}-2.55 \\
(2.48)\end{array}$ & $\begin{array}{r}-2.87 \\
(1.15)\end{array}$ & & $\begin{array}{r}-1.27 \\
(2.71)\end{array}$ & $\begin{array}{r}-1.50 \\
(2.72)\end{array}$ \\
\hline $\begin{array}{l}\text { Shock variables interacted with Ratio of } \\
\text { Endowment Value to Value when President took office } \\
p \text {-value of Shock-Ratio interactions }\end{array}$ & $\begin{array}{r}\text { No } \\
\mathrm{N} / \mathrm{A}\end{array}$ & $\begin{array}{r}\text { No } \\
\text { N/A }\end{array}$ & $\begin{array}{r}\text { No } \\
\mathrm{N} / \mathrm{A}\end{array}$ & $\begin{array}{r}\text { Yes } \\
0.182\end{array}$ & $\begin{array}{r}\text { Yes } \\
0.424\end{array}$ & $\begin{array}{r}\text { Yes } \\
0.424\end{array}$ & $\begin{array}{r}\text { No } \\
\text { N/A }\end{array}$ & $\begin{array}{r}\text { No } \\
\text { N/A }\end{array}$ & $\begin{array}{r}\text { No } \\
\text { N/A }\end{array}$ \\
\hline $\begin{array}{l}\text { Shock variables interacted with Tenure of } \\
\text { University President } \\
p \text {-value of Shock-Tenure interactions }\end{array}$ & $\begin{array}{l}\text { No } \\
\text { N/A }\end{array}$ & $\begin{array}{r}\text { No } \\
\text { N/A }\end{array}$ & $\begin{array}{l}\text { No } \\
\text { N/A }\end{array}$ & $\begin{array}{r}\text { No } \\
\text { N/A }\end{array}$ & $\begin{array}{r}\text { No } \\
\text { N/A }\end{array}$ & $\begin{array}{l}\text { No } \\
\text { N/A }\end{array}$ & $\begin{array}{r}\text { Yes } \\
0.841\end{array}$ & $\begin{array}{r}\text { Yes } \\
0.705\end{array}$ & $\begin{array}{r}\text { Yes } \\
0.602\end{array}$ \\
\hline $\begin{array}{l}\text { Revenue Shock Controls } \\
\text { University Fixed Effects } \\
\text { State-by-Year-by-Private Fixed Effects } \\
\text { R-squared (within) } \\
\text { Number of Observations }\end{array}$ & $\begin{array}{r}\text { No } \\
\text { Yes } \\
\text { Yes } \\
0.57 \\
2,004 \\
\end{array}$ & $\begin{array}{r}\text { No } \\
\text { Yes } \\
\text { Yes } \\
0.58 \\
2,004 \\
\end{array}$ & $\begin{array}{r}\text { Yes } \\
\text { Yes } \\
\text { Yes } \\
0.57 \\
1,991 \\
\end{array}$ & $\begin{array}{r}\text { No } \\
\text { Yes } \\
\text { Yes } \\
0.57 \\
2,004\end{array}$ & $\begin{array}{r}\text { No } \\
\text { Yes } \\
\text { Yes } \\
0.58 \\
2,004 \\
\end{array}$ & $\begin{array}{r}\text { Yes } \\
\text { Yes } \\
\text { Yes } \\
0.58 \\
1,991 \\
\end{array}$ & $\begin{array}{r}\text { No } \\
\text { Yes } \\
\text { Yes } \\
0.57 \\
2,004 \\
\end{array}$ & $\begin{array}{r}\text { No } \\
\text { Yes } \\
\text { Yes } \\
0.58 \\
2,004\end{array}$ & $\begin{array}{r}\text { Yes } \\
\text { Yes } \\
\text { Yes } \\
0.57 \\
1,991 \\
\end{array}$ \\
\hline
\end{tabular}

See the Appendix for variable definitions. "Near Benchmark" indicates that the value of the university endowment at the start of the year is $90-110 \%$ of the value of the endowment when the current university president took office. Standard errors, shown in parentheses, allow for correlations among observations of a given university over time as well as cross-sectional correlations. ${ }^{* * *},{ }^{*}$ denote significance at the $1 \%, 5 \%$, and $10 \%$ levels, respectively. 
Table 8: Relation between University Employment (Logarithm of Number of Employees) and Endowment Shocks

\begin{tabular}{|c|c|c|c|c|c|c|c|c|c|c|}
\hline & \multicolumn{2}{|c|}{ Tenure System } & \multicolumn{2}{|c|}{ Adjuncts } & \multicolumn{2}{|c|}{ Support } & \multicolumn{2}{|c|}{ Maintenance } & \multicolumn{2}{|c|}{ Administration } \\
\hline & (1) & (2) & (3) & (4) & (5) & (6) & (7) & (8) & (9) & (10) \\
\hline $\operatorname{Shock}_{i, t}^{+}=\operatorname{Max}\left(\operatorname{Shock}_{i, t}, 0\right)$ & $\begin{array}{r}0.01 \\
(0.03)\end{array}$ & $\begin{array}{l}-0.02 \\
(0.03)\end{array}$ & $\begin{array}{r}0.01 \\
(0.16)\end{array}$ & $\begin{array}{l}-0.06 \\
(0.16)\end{array}$ & $\begin{array}{l}-0.09 \\
(0.06)\end{array}$ & $\begin{array}{l}-0.07 \\
(0.06)\end{array}$ & $\begin{array}{r}0.00 \\
(0.05)\end{array}$ & $\begin{array}{r}-0.002 \\
(0.056)\end{array}$ & $\begin{array}{r}0.01 \\
(0.08)\end{array}$ & $\begin{array}{l}0.004 \\
(0.08)\end{array}$ \\
\hline $\operatorname{Shock}_{i, t}^{-}=\operatorname{Min}\left(\operatorname{Shock}_{i, t}, 0\right)$ & $\begin{array}{r}0.20 \\
(0.13)\end{array}$ & $\begin{array}{c}0.29^{* *} \\
(0.13)\end{array}$ & $\begin{array}{r}0.23 \\
(0.61)\end{array}$ & $\begin{array}{r}0.47 \\
(0.64)\end{array}$ & $\begin{array}{c}0.69^{* * *} \\
(0.21)\end{array}$ & $\begin{array}{c}0.65^{* * *} \\
(0.22)\end{array}$ & $\begin{array}{c}0.46^{* *} \\
(0.20)\end{array}$ & $\begin{array}{c}0.43^{* *} \\
(0.20)\end{array}$ & $\begin{array}{l}-0.21 \\
(0.28)\end{array}$ & $\begin{array}{l}-0.15 \\
(0.29)\end{array}$ \\
\hline $\operatorname{Shock}_{i, t-1}^{+}$ & $\begin{array}{r}0.03 \\
(0.03)\end{array}$ & $\begin{array}{r}0.05 \\
(0.03)\end{array}$ & $\begin{array}{l}-0.30^{* *} \\
(0.15)\end{array}$ & $\begin{array}{r}-0.24 \\
(0.15)\end{array}$ & $\begin{array}{r}0.07 \\
(0.05)\end{array}$ & $\begin{array}{r}0.06 \\
(0.05)\end{array}$ & $\begin{array}{r}0.02 \\
(0.05)\end{array}$ & $\begin{array}{r}0.02 \\
(0.05)\end{array}$ & $\begin{array}{l}-0.05 \\
(0.07)\end{array}$ & $\begin{array}{l}-0.04 \\
(0.07)\end{array}$ \\
\hline $\operatorname{Shock}_{i, t-1}^{-}$ & $\begin{array}{c}0.61^{* * *} \\
(0.19)\end{array}$ & $\begin{array}{l}0.61^{* * *} \\
(0.19)\end{array}$ & $\begin{array}{r}0.50 \\
(0.90)\end{array}$ & $\begin{array}{r}0.63 \\
(0.90)\end{array}$ & $\begin{array}{r}0.19 \\
(0.31)\end{array}$ & $\begin{array}{r}0.09 \\
(0.32)\end{array}$ & $\begin{array}{r}0.24 \\
(0.29)\end{array}$ & $\begin{array}{r}0.18 \\
(0.29)\end{array}$ & $\begin{array}{r}-0.32 \\
(0.41)\end{array}$ & $\begin{array}{l}-0.29 \\
(0.41)\end{array}$ \\
\hline $\operatorname{Rev}_{\text {Shock }}^{+}+t$ & & $\begin{array}{r}0.08 \\
(0.13)\end{array}$ & & $\begin{array}{c}1.33^{* *} \\
(0.62)\end{array}$ & & $\begin{array}{l}-0.53^{* *} \\
(0.25)\end{array}$ & & $\begin{array}{l}-0.44^{* *} \\
(0.22)\end{array}$ & & $\begin{array}{r}0.37 \\
(0.33)\end{array}$ \\
\hline $\operatorname{Rev~Shock}_{i, t}^{-}$ & & $\begin{array}{c}0.51^{* * *} \\
(0.18)\end{array}$ & & $\begin{array}{r}1.20 \\
(0.85)\end{array}$ & & $\begin{array}{r}-0.24 \\
(0.30)\end{array}$ & & $\begin{array}{r}0.14 \\
(0.31)\end{array}$ & & $\begin{array}{r}0.03 \\
(0.39)\end{array}$ \\
\hline $\operatorname{Rev}_{\text {Shock }}^{+}+t-1$ & & $\begin{array}{r}0.24 \\
(0.16)\end{array}$ & & $\begin{array}{r}1.35^{*} \\
(0.74)\end{array}$ & & $\begin{array}{l}-0.19 \\
(0.26)\end{array}$ & & $\begin{array}{r}0.09 \\
(0.23)\end{array}$ & & $\begin{array}{r}0.15 \\
(0.34)\end{array}$ \\
\hline $\operatorname{Rev}_{\text {Shock }}^{-} \overline{i, t-1}$ & & $\begin{array}{r}-0.24 \\
(0.18)\end{array}$ & & $\begin{array}{r}-0.94 \\
(0.85)\end{array}$ & & $\begin{array}{r}0.03 \\
(0.32)\end{array}$ & & $\begin{array}{r}0.19 \\
(0.28)\end{array}$ & & $\begin{array}{r}-0.33 \\
(0.42)\end{array}$ \\
\hline$p$-value of test $\operatorname{Shock}_{i, t}^{+}=\operatorname{Shock}_{i, t}^{-}$ & 0.158 & $0.033^{* *}$ & 0.749 & 0.445 & $0.001^{* * *}$ & $0.004^{* * *}$ & $0.038^{* *}$ & $0.056^{*}$ & 0.476 & 0.639 \\
\hline$p$-value of test $\operatorname{Shock}_{i, t-1}^{+}=\operatorname{Shock}_{i, t-1}^{-}$ & $0.001^{* * *}$ & $0.004^{* * *}$ & 0.369 & 0.357 & $0.026^{* *}$ & 0.916 & $0.068^{*}$ & 0.592 & 0.342 & 0.570 \\
\hline University Fixed Effects & Yes & Yes & Yes & Yes & Yes & Yes & Yes & Yes & Yes & Yes \\
\hline State-by-Year-by-Private Fixed Effects & Yes & Yes & Yes & Yes & Yes & Yes & Yes & Yes & Yes & Yes \\
\hline R-squared (within) & 0.83 & 0.83 & 0.66 & 0.66 & 0.86 & 0.86 & 0.36 & 0.36 & 0.59 & 0.59 \\
\hline Number of Observations & 3,003 & 2,980 & 3,002 & 2,979 & 2,396 & 2,392 & 2,292 & 2,289 & 2,396 & 2,392 \\
\hline
\end{tabular}

See the Appendix for variable definitions. Standard errors, shown in parentheses, allow for correlations among observations of a given university over time as well as cross-sectional correlations. ${ }^{* * *},{ }^{* *},{ }^{*}$ denote significance at the $1 \%, 5 \%$, and $10 \%$ levels, respectively. 


\section{Table 9: Relation between University Employment (Logarithm of Number of Employees) and the Interaction of Endowment Shocks with Endowment Size Being Near President's Benchmark}

\begin{tabular}{|c|c|c|c|c|c|}
\hline & $\begin{array}{c}\text { Tenure System } \\
(1)\end{array}$ & $\frac{\text { Adjuncts }}{\text { (2) }}$ & $\frac{\text { Support }}{\text { (3) }}$ & $\frac{\text { Maintenance }}{(4)}$ & $\frac{\text { Administration }}{\text { (5) }}$ \\
\hline $\operatorname{Shock}_{i, t}^{+}=\operatorname{Max}\left(\operatorname{Shock}_{i, t}, 0\right)$ & $\begin{array}{r}\mathbf{0 . 0 1} \\
(0.04)\end{array}$ & $\begin{array}{l}\mathbf{- 0 . 0 4} \\
(0.20)\end{array}$ & $\begin{array}{r}\mathbf{- 0 . 0 6} \\
(0.89)\end{array}$ & $\begin{array}{l}\mathbf{0 . 0 0 4} \\
(0.07)\end{array}$ & $\begin{array}{r}\mathbf{- 0 . 0 5} \\
(0.10)\end{array}$ \\
\hline Shock $_{i, t}^{+} *$ Near Benchmark & $\begin{array}{r}0.02 \\
(0.08)\end{array}$ & $\begin{array}{r}0.50 \\
(0.42)\end{array}$ & $\begin{array}{r}0.02 \\
(0.19)\end{array}$ & $\begin{array}{r}0.04 \\
(0.12)\end{array}$ & $\begin{array}{r}0.34^{*} \\
(0.19)\end{array}$ \\
\hline $\begin{array}{l}\text { Total effect of Shock } k_{i, t}^{+} \\
\text {when endowment near benchmark }\end{array}$ & 0.03 & 0.46 & -0.04 & 0.05 & 0.29 \\
\hline $\operatorname{Shock}_{i, t}^{-}=\operatorname{Max}\left(\operatorname{Shock}_{i, t}, 0\right)$ & $\begin{array}{r}\mathbf{0 . 3 4} \\
(0.15)\end{array}$ & $\begin{array}{r}\mathbf{0 . 6 4} \\
(0.76)\end{array}$ & $\begin{array}{r}\mathbf{0 . 3 4} \\
(1.48)\end{array}$ & $\begin{array}{r}\mathbf{0 . 2 7} \\
(0.22)\end{array}$ & $\begin{array}{r}-\mathbf{0 . 2 1} \\
(0.34)\end{array}$ \\
\hline Shock $_{i, t}^{-}$* Near Benchmark & $\begin{array}{l}\mathbf{0 . 4 3} \\
(0.19)\end{array}$ & $\begin{array}{r}\mathbf{0 . 1 7} \\
(0.95)\end{array}$ & $\begin{array}{r}\mathbf{0 . 3 6} \\
(1.27)\end{array}$ & $\begin{array}{r}\mathbf{0 . 2 1} \\
(0.27)\end{array}$ & $\begin{array}{r}-\mathbf{0 . 1 8} \\
(0.42)\end{array}$ \\
\hline $\begin{array}{l}\text { Total effect of Shock }{ }_{i, t}^{-} \\
\text {when endowment near benchmark }\end{array}$ & $0.76^{* * *}$ & 0.81 & $0.70^{* *}$ & 0.48 & -0.39 \\
\hline $\operatorname{Shock}_{i, t-1}^{+}$ & $\begin{array}{l}-\mathbf{0 . 0 1} \\
(0.04)\end{array}$ & $\begin{array}{l}\mathbf{- 0 . 1 8} \\
(0.19)\end{array}$ & $\begin{array}{r}\mathbf{0 . 0 2} \\
(0.06)\end{array}$ & $\begin{array}{l}-\mathbf{- 0 . 0 2} \\
(0.06)\end{array}$ & $\begin{array}{r}\mathbf{0 . 0 5} \\
(0.09)\end{array}$ \\
\hline Shock $_{i, t-1}^{+} *$ Near Benchmark & $\begin{array}{r}\mathbf{0 . 1 1 *} \\
(0.07)\end{array}$ & $\begin{array}{r}\mathbf{- 0 . 0 1} \\
(0.35)\end{array}$ & $\begin{array}{r}\mathbf{- 0 . 0 0 1} \\
(0.10)\end{array}$ & $\begin{array}{r}\mathbf{0 . 0 2} \\
(0.11)\end{array}$ & $\begin{array}{r}-\mathbf{0 . 2 3} \\
(0.15)\end{array}$ \\
\hline $\begin{array}{l}\text { Total effect of Shock } k_{i, t-1}^{+} \\
\text {when endowment near benchmark }\end{array}$ & 0.11 & -0.19 & 0.02 & -0.002 & -0.18 \\
\hline Shock $_{i, t-1}^{-}$ & $\begin{array}{r}\mathbf{0 . 4 1} \\
(0.25)\end{array}$ & $\begin{array}{r}\mathbf{0 . 0 2} \\
(1.24)\end{array}$ & $\begin{array}{r}\mathbf{0 . 1 0} \\
(0.37)\end{array}$ & $\begin{array}{r}\mathbf{0 . 0 3} \\
(0.35)\end{array}$ & $\begin{array}{r}-\mathbf{0 . 8 2} \\
(0.55)\end{array}$ \\
\hline Shock $_{i, t-1}^{-} *$ Near Benchmark & $\begin{array}{l}1.25^{* * *} \\
(0.49)\end{array}$ & $\begin{array}{r}3.38 \\
(2.42)\end{array}$ & $\begin{array}{l}\mathbf{- 0 . 4 1} \\
(0.72)\end{array}$ & $\begin{array}{l}-\mathbf{0 . 3 2} \\
(0.69)\end{array}$ & $\begin{array}{r}1.68 \\
(1.07)\end{array}$ \\
\hline $\begin{array}{l}\text { Total effect of Shock } k_{i, t-1}^{-} \\
\text {when endowment near benchmark }\end{array}$ & $1.66^{* * *}$ & 3.40 & -0.31 & -0.29 & 0.87 \\
\hline Revenue Shock Controls & Yes & Yes & Yes & Yes & Yes \\
\hline University Fixed Effects & Yes & Yes & Yes & Yes & Yes \\
\hline State-by-Year-by-Private Fixed Effects & Yes & Yes & Yes & Yes & Yes \\
\hline R-squared (within) & 0.87 & 0.69 & 0.88 & 0.42 & 0.64 \\
\hline Number of Observations & 2,224 & 2,230 & 1,765 & 1,690 & 1,765 \\
\hline
\end{tabular}

See the Appendix for variable definitions. The "Total effect of Shock ${ }_{i, t}^{+}$when endowment near benchmark" is the sum of the coefficient estimates on Shock ${ }_{i, t}^{+}$and its interaction with Near Benchmark. Other Shock variables are defined in a similar way. We omit the standard errors for the "Total effect of Shock $k_{i, t}^{+}$when endowment near benchmark" effects and only indicate their statistical significance. Near Benchmark indicates that the value of the university endowment at the start of the year is $90-110 \%$ of the value of the endowment when the current university president took office. Standard errors, shown in parentheses, allow for correlations among observations of a given university over time as well as cross-sectional correlations. ${ }^{* * *},{ }^{* *},^{*}$ denote significance at the $1 \%, 5 \%$, and $10 \%$ levels, respectively. 


\section{Appendix Table: Description of Variables}

Panel A: Dependent Variables

\begin{tabular}{|c|c|}
\hline Variable Name & Definition \\
\hline Endowment Payouts & $\begin{array}{l}\text { Payouts made by the endowment to the university } \\
\text { during the year. }\end{array}$ \\
\hline Payout Rate & $\begin{array}{l}\text { Payouts made by the endowment to the university } \\
\text { during the year divided by the endowment market } \\
\text { value at the start of the year (expressed in } \\
\text { percentage points). }\end{array}$ \\
\hline Deviation from Payout Policy & $\begin{array}{l}\text { Payouts made by the endowment to the university } \\
\text { during the year less the amount of payouts that } \\
\text { would be implied by the endowment's payout } \\
\text { policy, divided by the endowment market value at } \\
\text { the start of the year (expressed in percentage } \\
\text { points). }\end{array}$ \\
\hline Tenure System & $\begin{array}{l}\text { Logarithm of the number of tenure-system } \\
\text { faculty. }\end{array}$ \\
\hline Adjuncts & Logarithm of the number of adjuncts/lecturers. \\
\hline Support & $\begin{array}{l}\text { Logarithm of the number of support staff (e.g., } \\
\text { secretaries). }\end{array}$ \\
\hline Maintenance & $\begin{array}{l}\text { Logarithm of the number of maintenance } \\
\text { employees. }\end{array}$ \\
\hline Administration & Logarithm of the number of administrators. \\
\hline
\end{tabular}




\section{Appendix Table: Description of Variables (continued)}

Panel B: Explanatory Variables

\begin{tabular}{|c|c|}
\hline Variable Name & Definition \\
\hline Return $_{i, t}$ & Return of the endowment during the year. \\
\hline Returni, $t+$ & $\operatorname{Max}\left(\operatorname{Return}_{i, t}, 0\right)$ \\
\hline $\operatorname{Return}_{i, t}^{-}$ & $\operatorname{Min}\left(\operatorname{Return}_{i, t}, 0\right)$. \\
\hline Shock $_{i, t}$ & Return $_{i, t} \times \frac{\text { Endow mentFund Size }_{i, t-1}}{{\text { Total University } \operatorname{Costs}_{i, t-1}}}$ \\
\hline $\operatorname{Shock}_{i, t}^{+}$ & $\operatorname{Max}\left(\right.$ Shock $\left._{i, t}, 0\right)$. \\
\hline $\operatorname{Shock}_{i, t}^{-}$ & $\operatorname{Min}\left(\operatorname{Shock}_{i, t}, 0\right)$ \\
\hline Shock $_{i, t-1}^{+}$ & One-year-lagged value of Shock $_{i, t}^{+}$ \\
\hline Shock $_{i, t-1}^{-}$ & $\begin{array}{l}\text { One-year-lagged value of } \operatorname{Shock}_{i, t}^{-} \\
\qquad \text { Endowment Fund Size }_{i t-1}\end{array}$ \\
\hline Rev Shock ${ }_{i, t}$ & $\%$ Change in Revenue ${ }_{i, t} \times \frac{\text { Total University Costs }}{i, t-1}$ \\
\hline $\operatorname{Rev}_{S^{\prime}} \operatorname{sk}_{i, t}^{+}$ & $\operatorname{Max}($ Rev Shock, 0$)$ \\
\hline $\operatorname{Rev}_{\text {Shock }}^{-}$ & Min (Rev Shock, 0). \\
\hline $\operatorname{Rev}_{S^{\prime}} \mathrm{Sh}_{i, t-1}^{+}$ & One-year-lagged value of Rev Shock ${ }_{i, t}^{+}$ \\
\hline $\operatorname{Rev}_{\text {Shock }}^{-} \overline{i, t-1}$ & One-year-lagged value of Rev Shock $\overline{i, t}$ \\
\hline Near Benchmark & $\begin{array}{l}\text { Indicator variable that takes the value of one if the value } \\
\text { of the university endowment at the start of the year is } \\
90-110 \% \text { of the value of the endowment when the } \\
\text { current university president took office and zero } \\
\text { otherwise. }\end{array}$ \\
\hline
\end{tabular}

